\title{
Microbial Flocculants as an Alternative to Synthetic Polymers for Wastewater Treatment: A Review
}

\author{
Faouzi Ben Rebah ${ }^{1,2, *(\mathbb{C}, \text { Wissem Mnif }}{ }^{3,4}$ a and Saifeldin M. Siddeeg ${ }^{1,5,6}$ \\ 1 Department of Chemistry, College of Science, King Khalid University, P. O. Box 9004, \\ Abha 61413, Kingdom of Saudi Arabia; saif.siddeeg@gmail.com \\ 2 Higher Institute of Biotechnology of Sfax (ISBS), Sfax University, P. O. Box 263, Sfax 3000, Tunisia \\ 3 Faculty of Sciences and Arts in Balgarn, University of Bisha, P. O. Box 60, \\ Balgarn-Sabt Al Olaya 61985, Kingdom of Saudi Arabia; w_mnif@yahoo.fr \\ 4 LR11-ES31 Laboratory of Biotechnology and Valorisation of Bio-Geo Resources, Higher Institute of \\ Biotechnology of Sidi Thabet, BiotechPole of Sidi Thabet, University of Manouba, Biotechpole Sidi Thabet, \\ 2020 Ariana, Tunisia \\ 5 Research Center for Advanced Materials Science (RCAMS), King Khalid University, P. O. Box 9004, \\ Abha 61413, Kingdom of Saudi Arabia \\ 6 Chemistry and Nuclear Physics Institute, Atomic Energy Commission, P. O. Box 3001, \\ Khartoum 11111, Sudan \\ * Correspondence: benrebahf@yahoo.fr
}

Received: 29 September 2018; Accepted: 24 October 2018; Published: 1 November 2018

\begin{abstract}
Microorganisms such as bacteria, fungi, and microalgae have been used to produce bioflocculants with various structures. These polymers are active substances that are biodegradable, environmentally harmless, and have flocculation characteristics. Most of the developed microbial bioflocculants displayed significant flocculating activity (FA $>70-90 \%$ ) depending on the strain used and on the operating parameters. These biopolymers have been investigated and successfully used for wastewater depollution in the laboratory. In various cases, selected efficient microbial flocculants could reduce significantly suspended solids (SS), turbidity, chemical oxygen demand (COD), total nitrogen $(\mathrm{Nt})$, dye, and heavy metals, with removal percentages exceeding $90 \%$ depending on the bioflocculating materials and on the wastewater characteristics. Moreover, bioflocculants showed acceptable results for sludge conditioning (accepted levels of dry solids, specific resistance to filtration, moisture, etc.) compared to chemicals. This paper explores various bioflocculants produced by numerous microbial strains. Their production procedures and flocculating performance will be included. Furthermore, their efficiency in the depollution of wastewater will be discussed.
\end{abstract}

Keywords: microbial flocculants; wastewater treatment; growth media; coagulation-flocculation

\section{Introduction}

The conventional coagulation-flocculation technique applied for wastewater treatment is widely used, showing significant treatment efficiency regarding the removal of organic material, suspended solids, and heavy metals [1]. In addition, it provides benefits for the wastewater treatment system, such as higher resistance to toxic loadings and massive amounts of organics, conducting simplicity, energy savings, etc. [2]. The chemical flocculants universally used in this process included inorganic (polyaluminum chloride, ferric chloride, etc.) and organic flocculants (such as polyacrylamide and its derivatives) [3]. These chemicals stay in wastewater after treatment and sludge and may cause health and ecological complications [4]. Consequently, the discarding of treated wastewater in the environment may cause serious disadvantages for human health, since the used chemicals are reported to be related to various health effects (Alzheimer's disease, neurotoxicity, carcinogenic, genotoxic 
properties, etc.) [5]. Residual chemicals destroy aquatic life and make the water inappropriate for human consumption. Both synthetic organic and inorganic flocculants were reported to be responsible for neurotoxicity and carcinogenicity. It was also demonstrated that Alzheimer's disease is linked to aluminum remaining in treated water [6]. A recent study showed the toxicity of both anionic polyacrylamide and cationic polymers for aquatic invertebrates and fish [7]. In this context, it was reported that cationic polymers tend to accumulate in fish gills, interfering with gill function and ion regulation, causing fish death and consequently reducing the supply of healthy fish for human consumption [8]. Moreover, monomers resulting from the degradation of polyacrylamide under specific environmental conditions are considered to be a likely human carcinogen and neurotoxin. Therefore, many authorities have restricted the use of chemical polymers in various industrial applications [9]. In addition, these products are costly and may not be available locally. Hence, there is a need to consider other flocculants offering a new sustainable strategy. This sustainable approach is based on the use of bioflocculants in the coagulation-flocculation treatment for the removal of pollutants from wastewater [5]. Natural biological origin materials, such as beans, moringa, maize, cactus, etc., were investigated [5]. Recently, more attention has been diverted to microbial flocculants produced by various microorganisms (actinomycetes, fungi, bacteria, and algae) widely distributed in soil and water [10-12]. Microbial flocculants that are produced during the microorganism growth varied in composition (polysaccharides, proteins, DNA, cellulose, sugar, protein, polyamino acids, etc.). They are active biocompounds, biodegradable, without degraded intermediate pollutants, environmentally harmless, and have flocculation properties. For these reasons, examinations were carried out to determine their efficiency for wastewater treatment from various origins. This review aims to explore the production of microbial flocculants and their applications in wastewater treatments.

\section{Bioflocculant-Producing Microorganisms}

Bacteria, fungi, and microalgae were showed to produce bioflocculants. Microorganisms are selected based on various factors (morphology, the presence of slimy extracellular polysaccharides, etc.) using different methods and reagents (Congo red, crystal violet and $\mathrm{CuSO}_{4}$ solution, chelating agents, colorimetric methods, etc.). The flocculating activity (FA) was commonly evaluated using a kaolin suspension. The produced bioflocculant was also subject to qualitative analyses. Fourier transfer infrared radiation was used to analyze the structure of the bioflocculant. Interestingly, many sources (sludge, soil, sediments, river, seawater, etc.) were investigated to isolate microorganisms that yield flocculating substances (e.g., polysaccharides, proteins, and glycoproteins).

\subsection{Bacteria}

Several bacterial strains belonging to various classes (Actinobacteria, Alphaproteobacteria, Bacilli, Deltaproteobacteria, Gammaproteobacteria, Proteobacteria, etc.) have been reported to produce flocculants (Table 1) [13-49]. For example, salt production pond Bacillus mojavensis strain 32A was found to produce proteoglycan flocculant $(98.4 \%$ polysaccharide and $1.6 \%$ protein) with an interesting FA of $96.11 \%$ recorded at $\mathrm{pH} 10$ [14]. In the presence of specific growth conditions (L-glutamic acid and $\mathrm{NH}_{4} \mathrm{Cl}$ as nutrient sources), this strain yields $5.2 \mathrm{~g} / \mathrm{L}$ of the extracted biopolymer. Another Bacillus strain isolated from freshwater (Bacillus pumilus ZAP 028) produced a thermostable and wide $\mathrm{pH}$ range flocculating agent $(\mathrm{FA}=69.8 \%)$ [18]. In this case, results were obtained in the presence of maltose and several nitrogen sources (e.g., yeast extract, urea and ammonium sulfate) with $4 \%(v / v)$ of inoculum and $\mathrm{pH} 7$. The bioflocculant content was $75.4 \%$ polysaccharide, $5.3 \%$ protein, and $15.4 \%$ uronic acid [18]. 
Table 1. Examples of bacteria investigated for flocculant production.

\begin{tabular}{|c|c|c|c|}
\hline Strain (Source) & Carbon/Nitrogen Sources & $\begin{array}{c}\text { FA }{ }^{1 / \text { Flocculant Composition }} \\
\left(\mathrm{PS}^{2}, \mathrm{P}^{3}\right)\end{array}$ & Reference \\
\hline $\begin{array}{l}\text { Bacillus agaradhaerens C9 } \\
\text { (alkaline lake) }\end{array}$ & glucose, yeast extract & $\begin{array}{c}\text { FA: } 80.63 \% \\
\text { PS: } 65.42 \%, \text { P: } 4.70 \%\end{array}$ & {$[13]$} \\
\hline $\begin{array}{l}\text { Bacillus mojavensis 32A } \\
\text { (salt production pond) }\end{array}$ & L-glutamic acid, $\mathrm{NH}_{4} \mathrm{Cl}$ & $\begin{array}{c}\text { FA: } 96.11 \% \\
\text { PS: } 98.4 \%, P: 1.60 \%\end{array}$ & {$[14]$} \\
\hline $\begin{array}{c}\text { Bacillus sp. XF-56 } \\
\text { (marine intertidal sludge) }\end{array}$ & glucose, yeast extract & FA: $93.5 \%$ & [13] \\
\hline $\begin{array}{c}\text { Bacillus subtilis F9 } \\
\text { (wastewater sludge) }\end{array}$ & sucrose, peptone & $\begin{array}{c}\text { FA: } 90 \% \\
\text { PS: } 88.3 \%, \text { P: } 10.10 \%\end{array}$ & {$[15]$} \\
\hline $\begin{array}{l}\text { Bacillus licheniformis X14 } \\
\text { (soil) }\end{array}$ & beef extract, peptone & $\begin{array}{c}\text { FA: } 98 \% \\
\text { PS: } 91.5 \%, \text { P: } 8.4 \%\end{array}$ & [16] \\
\hline Bacillus licheniformis & glucose, $\mathrm{NH}_{4} \mathrm{Cl}$ & $\begin{array}{c}\text { FA: } 96 \% \\
\text { PS: } 91 \%, \text { P: } 9 \%\end{array}$ & [17] \\
\hline Bacillus firmus & glucose, $\mathrm{NH}_{4} \mathrm{Cl}$ & FA: $89 \%$ & [17] \\
\hline $\begin{array}{l}\text { Bacillus pumilus } \\
\text { (fresh water) }\end{array}$ & $\begin{array}{l}\text { maltose, yeast extract, urea, } \\
\text { ammonium sulfate }\end{array}$ & FA: $69.8 \%$ & {$[18]$} \\
\hline $\begin{array}{l}\text { Bacillus CPO8, Bacillus CPO13 and } \\
\text { Pseudomonas CPO14 } \\
\text { (contaminated crude petroleum oil) }\end{array}$ & glucose, $\mathrm{NH}_{4} \mathrm{Cl}$ & $\begin{array}{l}\text { FA: } 92.17-97.59 \% \\
\text { PS: } 91 \%, \text { P: } 9 \%\end{array}$ & {$[19]$} \\
\hline $\begin{array}{l}\text { Bacillus velezensis } 40 \mathrm{~B} \\
\text { (brackish water) }\end{array}$ & glucose, yeast extract & $\begin{array}{c}\text { FA }>98 \% \\
\text { PS: } 98 \%, \text { P: } 2 \%\end{array}$ & {$[20]$} \\
\hline $\begin{array}{l}\text { Bacillus cereus } \\
\text { (cultivated soil) }\end{array}$ & starch, yeast extract & $\begin{array}{c}\text { FA: } 75 \% \\
\text { PS: } 16.99 \%, \text { P: } 3.01 \%\end{array}$ & {$[21]$} \\
\hline Bacillus cereus (soil) & $\begin{array}{l}\text { glucose, sucrose, fructose, } \\
\text { lactose, starch, urea, peptone, } \\
\text { yeast extract }\end{array}$ & $\begin{array}{c}\text { FA: } 75 \% \\
\text { PS: } 91 \%, \text { P: } 9 \%\end{array}$ & [21] \\
\hline Bacilli subtilis CZ1003 & glucose, beef extract & FA: $36.2 \%$ & {$[22]$} \\
\hline Bacillus subtilis & glycerol, $\mathrm{NH}_{4} \mathrm{Cl}$ & $\begin{array}{c}\text { FA: } 23.77 \% \\
\text { Poly- } \gamma \text {-glutamic acid }\end{array}$ & [23] \\
\hline $\begin{array}{l}\text { Bacillus thuringiensis } \\
\text { (cultivated soil) }\end{array}$ & starch, yeast extract & $\begin{array}{c}\text { FA: } 76.3 \% \\
\text { PS: } 15.23 \%, \text { P: } 84.73 \%\end{array}$ & [21] \\
\hline $\begin{array}{c}\text { Solibacillus silvestris W01 } \\
\text { (activated sludge) }\end{array}$ & sorbitol or starch, yeast extract & $\begin{array}{c}\text { FA: } 90 \% \\
\text { P: } 75.1 \%, P: 24.9 \%\end{array}$ & {$[24]$} \\
\hline $\begin{array}{l}\text { Paenibacillus elgii B69 } \\
\text { (soil) }\end{array}$ & sucrose, peptone, yeast extract & $\begin{array}{l}\text { FA: } 90 \% \\
\text { P: } 100 \%\end{array}$ & [25] \\
\hline $\begin{array}{l}\text { Paenibacillus mucilaginosus GIM1.16 } \\
\text { (soil) }\end{array}$ & sucrose, yeast extract & $\begin{array}{l}\text { FA: } 89.7 \% \\
\text { P: } 100 \%\end{array}$ & [26] \\
\hline $\begin{array}{c}\text { Pantoea agglomerans BH18 } \\
\text { (mutant strain 2-103) }\end{array}$ & $\begin{array}{l}\text { glucose, tryptone, yeast } \\
\text { extract, beef extract }\end{array}$ & FA: $87.5 \%$ & [27] \\
\hline $\begin{array}{l}\text { Chryseobacterium daeguense W6 } \\
\text { (biological aerated filter sludge) }\end{array}$ & glucose, tryptone & $\begin{array}{c}\text { FA: } 96.9 \% \\
\text { PS: } 13.1 \%, \text { P: } 32.4 \%\end{array}$ & [28] \\
\hline $\begin{array}{l}\text { Proteus mirabilis } \\
\text { (activated sludge) }\end{array}$ & glucose, peptone & FA: $92.8 \%$ & [29] \\
\hline $\begin{array}{l}\text { Proteus mirabilis } \\
\text { (activated sludge) }\end{array}$ & glucose, peptone & $\begin{array}{l}\text { FA: } 95.6 \% \\
\text { PS and P }\end{array}$ & [29] \\
\hline $\begin{array}{l}\text { Klebsiella sp. PB12 } \\
\quad \text { (river water) }\end{array}$ & $\begin{array}{l}\text { nutrient poor medium (with } \\
\text { glucose or lactose or mannose) }\end{array}$ & $\begin{array}{c}\text { FA: } 80 \% \\
\text { PS: } 72.32 \%, \text { P: } 14.12 \%\end{array}$ & {$[30]$} \\
\hline $\begin{array}{l}\text { Klebsiella sp. ZZ-3 } \\
\text { (activated sludge) }\end{array}$ & glucose, $\mathrm{NaNO}_{3}, \mathrm{NH}_{4} \mathrm{Cl}$, urea & $\begin{array}{c}\text { FA: } 94.5 \% \\
\text { PS: } 84.6 \%, \text { P: } 6.1 \%\end{array}$ & {$[31]$} \\
\hline $\begin{array}{c}\text { Klebsiella sp. TG-1 } \\
\text { (starch factory wastewater) }\end{array}$ & $\begin{array}{l}\text { sucrose, yeast extracts, beef } \\
\text { extract (using trona } \\
\text { suspension) }\end{array}$ & FA: $86.9 \%$ PS: $84.6 \%$, P: $11.1 \%$ & {$[32]$} \\
\hline $\begin{array}{c}\text { Pseudomonas } \\
\text { Aeruginosa }\end{array}$ & $\begin{array}{l}\text { petroleum hydrocarbons, } \\
\text { peptone }\end{array}$ & $\begin{array}{l}\text { FA: } 87.8 \% \\
\text { PS and P }\end{array}$ & {$[33]$} \\
\hline $\begin{array}{l}\text { Turicibacter sanguinis } \\
\text { (wastewater sludge) }\end{array}$ & $\begin{array}{c}\text { methanol wastewater } \\
\left(\mathrm{NH}_{4}\right)_{2} \mathrm{SO}_{4} \text {, yeast extract }\end{array}$ & $\begin{array}{c}\text { FA: ND }{ }^{4} \\
\text { PS: } 74.1 \%, \text { P: } 24.2 \%\end{array}$ & {$[34]$} \\
\hline
\end{tabular}


Table 1. Cont.

\begin{tabular}{|c|c|c|c|}
\hline Strain (Source) & Carbon/Nitrogen Sources & 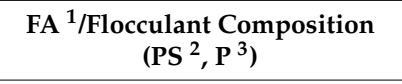 & Reference \\
\hline Arthrobacter sp. B4 & glucose, yeast extract & $\begin{array}{l}\text { FA: } 99 \% \\
\text { PS: } 100 \%\end{array}$ & [35] \\
\hline $\begin{array}{l}\text { Streptomyces sp. MBRC-91 } \\
\text { (sourse NI) }\end{array}$ & $\begin{array}{l}\text { palm jiggery, yeast extract, } \\
\qquad \mathrm{NH}_{4} \mathrm{NO}_{2}\end{array}$ & FA: $96.3 \%$ & [36] \\
\hline Achromobacter sp TL-3 (activate sludge) & $\begin{array}{c}\text { ethanol, glycerol, peptone, } \\
\text { yeast extract }\end{array}$ & FA: $95 \%$ & [37] \\
\hline Rhodococcus opacus (sourse $\mathrm{NI}^{5}$ ) & glucose, yeast extract & $\begin{array}{c}\text { FA: } 82 \% \\
\text { PS: } 64.6 \%, \text { P: } 9.44 \%\end{array}$ & [38] \\
\hline $\begin{array}{l}\text { Rhodococcus erythropolis } \\
\text { (activated sludge) }\end{array}$ & swine wastewater & $\begin{array}{l}\text { FA: } 94.5 \% \\
\text { P: } 99.2 \%\end{array}$ & [39] \\
\hline $\begin{array}{l}\text { Rhodococcus rhodochrous } \\
\text { (sourse NI) }\end{array}$ & glucose, $\mathrm{NH}_{4} \mathrm{Cl}$ & $\begin{array}{c}\text { FA: } 22.5 \% \\
\text { PS: } 62.86 \%, P: 10.36 \%\end{array}$ & [40] \\
\hline $\begin{array}{l}\text { Halomonas stenophila } \\
\text { HK30(saline-wetland) }\end{array}$ & MY medium & $\begin{array}{c}\text { FA: } 72.06 \% \\
\text { sulphated heteropolysaccharide }\end{array}$ & [41] \\
\hline $\begin{array}{l}\text { Halomonas sp. AAD6 } \\
\text { (camaltı saltern area) }\end{array}$ & pretreated molasses & $\begin{array}{l}\text { FA: ND PS: } 90 \%, \\
\text { P: } 0.5 \%\end{array}$ & [42] \\
\hline $\begin{array}{l}\text { Agrobacterium sp. M-503 (propylene } \\
\text { epoxide wastewater sludge) }\end{array}$ & sucrose, yeast extract, urea & $\begin{array}{c}\text { FA: } 74.5 \% \text { PS: } 85 \% \\
\text { P: } 3 \%\end{array}$ & [43] \\
\hline $\begin{array}{l}\text { Rothia sp. (Ruditapes philippinarum } \\
\text { conglutination mud) }\end{array}$ & $\begin{array}{l}\text { saccharose, }\left(\mathrm{NH}_{4}\right)_{2} \mathrm{SO}_{4} \\
\text { peptone }\end{array}$ & $\begin{array}{c}\text { FA: } 86.22 \% \\
P\end{array}$ & [44] \\
\hline $\begin{array}{l}\text { Chryseobacterium daeguense } \\
\text { W6 (source NI) }\end{array}$ & glucose, tryptone, $\mathrm{Mg}\left(\mathrm{NO}_{3}\right)_{2}$ & $\begin{array}{l}\text { FA: } 90 \% \\
\text { PS and P }\end{array}$ & [45] \\
\hline Strain B31 (source NI) & glucose, urea & $\begin{array}{l}\text { FA: } 90.21 \% \\
\text { PS and P }\end{array}$ & [46] \\
\hline $\begin{array}{l}\text { Various bacterial isolates } \\
\text { (tapioca wastewater) }\end{array}$ & $\begin{array}{l}\text { glucose, sucrose, peptone, } \\
\text { yeast extract, urea }\end{array}$ & FA: $13.54-71.38 \%$ & [47] \\
\hline Methylobacterium sp. Obi (river water) & glucose, peptone & $\begin{array}{l}\text { FA: } 72 \% \\
\text { PS }\end{array}$ & [48] \\
\hline $\begin{array}{l}\text { Bacillus cereus and Pichia membranifaciens } \\
\text { (activated sludge) }\end{array}$ & alcohol, urea & FA: $40-90 \%$ & [49] \\
\hline
\end{tabular}

More recently, two isolates from Egyptian soil (Bacillus cereus and Bacillus thuringiensis) were reported to produce a significant amount of bioflocculants [21]. The total carbohydrate bioflocculant contents were $16.99 \%$ and $15.27 \%$, while the total protein content were $83.01 \%$ and $84.73 \%$, respectively, for Bacillus cereus and Bacillus thuringiensis. The maximum FA ( $75 \%$ to $76.3 \%$, respectively, for Bacillus cereus and Bacillus thuringiensis) were obtained at $\mathrm{pH} 7-8$ and temperature $30-40{ }^{\circ} \mathrm{C}$ during the growth period from 72 to $96 \mathrm{~h}$ and in the presence of starch and yeast extract [21]. Different carbon sources were used for the growth of sludge-isolated strain (Bacillus sp. XF-56). However, glucose was most favorable for bioflocculant production (FA $=93.5 \%)$. Interestingly, at the initial $\mathrm{pH}(5-10)$, this strain yields hydrogen (optimum yield at $\mathrm{pH}=7$ ) and bioflocculants (optimum yield at $\mathrm{pH}=8$ ). This strain resists higher salt concentration, offering broad application potential for fresh and marine wastewater [13].

Likewise, several strains belonging to the Gamma proteobacteria class were isolated from various sources. River water [30], activated sludge [31] and starch wastewater [32] were used to select Klebsiella sp. strains. For example, Klebsiella sp. ZZ-3, isolated from activated sludge yields an effective, $\mathrm{pH}$-tolerant, and thermostable bioflocculant [31]. In this case, the bioflocculant composition was found to be $84.6 \%$ polysaccharides (containing, specifically, rhamnose, mannose, and galactose) and $6.1 \%$ protein. Starch wastewater was also used to isolate another strain (Klebsiella sp. TG-1). The purified microbial flocculant consisting of polysaccharides and proteins ( $84.6 \%$ and $11.1 \%$, respectively) showed a FA of $86.9 \%$ obtained with trona suspension [32]. 
Bacterial strains belonging to the Actinobacteria class (Arthrobacter, Rhodococcus sp. Streptomyces, etc.) were investigated by many researchers. Rhodococcus erythropolis isolated from activated sludge was cultivated in swine wastewater as a carbon and nitrogen source. The produced flocculant consist mainly of protein (99.2\%) with higher FA of 99.2\% [39]. However, another strain (Rhodococcus rhodochrous) growing in the presence of glucose and $\mathrm{NH}_{4} \mathrm{Cl}$ produced proteoglycan flocculant $(62.86 \%$ polysaccharide and $10.3 \%$ protein) with a lower FA (22.5\%)) [40].

Nevertheless, many strains belonging to the Proteobacteria class possess the ability to synthesize bioflocculants. For example, a strain identified as Agrobacterium sp. M-503 (from propylene epoxide wastewater sludge) produced a biopolymer ( $85 \%$ p polysaccharide and $3 \%$ protein) with an acceptable level of FA (75\%) [43]. Amjres et al. (2015) [41] isolated Halomonas stenophila HK30 from saline wetland that is able to produce sulphated heteropolysaccharide with an efficient FA $(72.06 \%)$.

Based on the collected information, the majority of research activities has mainly been oriented to the isolation of new strains and the production of bioflocculant using pure culture. However, the possibility was reported recently of combining microbial strains to produce bioflocculants with better FA than pure strains. Table 2 [50-58] presents several consortia evaluated for their bioflocculant production.

Table 2. Examples of microbial consortia investigated for bioflocculant production.

\begin{tabular}{|c|c|c|c|}
\hline Consortium (Source) & Carbon/Nitrogen Sources & FA ${ }^{1}$ and Flocculant Composition $\left(\mathrm{PS}^{2}, \mathrm{P}^{3}\right)$ & Reference \\
\hline $\begin{array}{c}\text { Cobetia sp. OAUIFE, Bacillus sp. MAYA } \\
\text { (sediment) }\end{array}$ & $\begin{array}{l}\text { glucose, urea, yeast extract, } \\
\left(\mathrm{NH}_{4}\right)_{2} \mathrm{SO}_{4}\end{array}$ & $\begin{array}{c}\text { FA: } 90 \% \\
\text { uronic acid: } 66 \%, \mathrm{P}: 31 \%\end{array}$ & [50] \\
\hline $\begin{array}{l}\text { Cobetia sp. OAUIFE, Bacillus sp. MAYA, } \\
\text { and Bacillus sp. Gilbert (sediment) }\end{array}$ & $\begin{array}{l}\text { glucose, urea, yeast extract, } \\
\qquad\left(\mathrm{NH}_{4}\right)_{2} \mathrm{SO}_{4}\end{array}$ & $\begin{array}{c}\text { FA: } 87.4 \% \text { (kaolin) } \\
\text { F A: } 96.4 \% \text { (river water) } \\
\text { FA: } 93.7 \% \text { (brewery wastewater) } \\
\text { FA: } 82.2 \% \text { (dairy wastewater) } \\
\text { PS and P }\end{array}$ & [51] \\
\hline $\begin{array}{l}\text { Staphylococcus sp. BAFRT4, Pseudomonas } \\
\text { sp. CYGS1 (source NI }{ }^{4} \text { ) }\end{array}$ & Brewery wastewater & $\begin{array}{l}\text { FA: } 96.8 \% \\
\text { PS and P } \\
\end{array}$ & [52] \\
\hline $\begin{array}{c}\text { Different stains } \\
\text { (pharmaceutical, sugar and hoggery } \\
\text { waste water) }\end{array}$ & sucrose, yeast extract, urea & FA: $76 \%$ & [53] \\
\hline $\begin{array}{l}\text { Halomonas sp. Okoh and Micrococcus sp. } \\
\text { Leo (sediment) }\end{array}$ & glucose, yeast extract & $\begin{array}{c}\text { FA: } 86 \% \\
\text { Polycoprotein }\end{array}$ & [54] \\
\hline $\begin{array}{l}\text { Halobacillus sp. Mvuyo and } \\
\text { Oceanobacillus sp. Pinky (sediment) }\end{array}$ & $\begin{array}{c}\text { sodium carbonate, urea, yeast } \\
\text { extract, }\left(\mathrm{NH}_{4}\right)_{2} \mathrm{SO} 4\end{array}$ & $\begin{array}{l}\text { FA: } 98.3 \% \\
\text { PS and P }\end{array}$ & [55] \\
\hline $\begin{array}{c}\text { Streptomyces sp. Gansen } \\
\text { and Cellulomonas sp. Okoh } \\
\text { (river) }\end{array}$ & sucrose, peptone & $\begin{array}{l}\text { FA: } 98.9 \% \\
\text { PS and } P\end{array}$ & [56] \\
\hline $\begin{array}{l}\text { Biological sludge } \\
\text { (municipal sewage) }\end{array}$ & NI & $\begin{array}{c}\text { FA: } 98.5 \% \\
\text { amino-polysaccharide }\end{array}$ & [57] \\
\hline $\begin{array}{l}\text { Biological sludge } \\
\text { (municipal sewage) }\end{array}$ & NI & $\begin{array}{l}\text { FA: } 99.5 \% \\
\text { PS }\end{array}$ & [58] \\
\hline
\end{tabular}

A culture mixture of Cobetia sp. OAUIFE and Bacillus sp. MAYA produces a bioflocculant containing $66 \%$ uronic acid and $31 \%$ protein. At a flocculant dose of $0.8 \mathrm{mg} / \mathrm{mL}$, at $\mathrm{pH} 8$ and in the presence of $\mathrm{Ca}^{2+}$, optimum FA (90\%) was obtained [50]. Similarly, a produced bioflocculant by growing both Halomonas sp. Okoh and Micrococcus sp. Leo was shown to be controlled by $\mathrm{Ca}^{2+}, \mathrm{Mn}^{2+}$ and $\mathrm{Al}^{3+}$, thermostable and active at $\mathrm{pH}(2-10)$, with an optimum $\mathrm{FA}$ of $86 \%$ at $\mathrm{pH}$. Consequently, the bioflocculant may be used to replace the synthetic flocculants widely used in wastewater treatment [54]. An interesting bioflocculant $(\mathrm{FA}=98.9 \%)$ was also produced by a mixture of Streptomyces sp. Gansen and Cellulomonas sp. Okoh [56] grown in an optimized medium (containing sucrose, peptone, and magnesium chloride). It has been reported that the extracted bioflocculant contains polysaccharides (neutral sugar, amino sugar, and uronic acids) and proteins [56]. Because bioflocculation represents a dynamic process occurring in an aerobic activated sludge system, the sludge may contain large numbers of bioflocculant-producing microbial strains. Microorganism aggregate of the biological sludge secretes mainly flocculating materials (e.g., polysaccharides, proteins, glycoproteins, etc.) at different concentrations. Biological sludge 
from municipal wastewater was used for bioflocculant production by Zhang et al. (2013) [57] and Sun et al. (2012) [58]. In these studies, hydrochloric acid treatments were used to extract flocculating active ingredients. The highest flocculating rate fraction can be purified from the crude bioflocculant. The conducted experiment allowed the purification of an amino-polysaccharide bioflocculant with an optimum FA of $98.5 \%$ at $\mathrm{pH} 10.5$ and $3.0 \%(v / v)$ as a dose [57]. Likewise, FA of the purified polysaccharide reached $99.5 \%$ at the same conditions $(3.0 \% v / v$ and $\mathrm{pH} 10.5)$ [58].

\subsection{Fungi and Microalgae}

A limited number of studies on fungal bioflocculant have been reported (Table 3) [3,59-68]. Among the isolated fungal strains, Aspergillus flavus was shown to produce a bioflocculant composed mainly of polysaccharide $(69.7 \%)$ and protein $(28.5 \%)$, with an excellent FA $(<90 \%)$ without cation addition. Interestingly, the use of sucrose and peptone allowed optimal bioflocculant production [3].

Table 3. Examples of fungi and algae investigated for bioflocculant production.

\begin{tabular}{|c|c|c|c|}
\hline Strain (Source) & Carbon/Nitrogen Sources & FA $^{1}$ and Flocculant Composition (PS $\left.{ }^{2}, \mathrm{P}^{3}\right)$ & Reference \\
\hline $\begin{array}{l}\text { Aspergillus flavus } \\
\text { (source } \mathrm{NI}^{3} \text { ) }\end{array}$ & $\begin{array}{l}\text { sucrose, } \\
\text { peptone }\end{array}$ & $\begin{array}{c}\text { FA }>90 \% \\
\text { PS: } 69.7 \%, \text { P: } 28.5 \%\end{array}$ & [3] \\
\hline $\begin{array}{l}\text { Penicillum strain HHE-P7 } \\
\text { (source NI) }\end{array}$ & $\begin{array}{c}\text { glucose, } \\
\text { yeast extract }\end{array}$ & FA: $96 \%$ & [59] \\
\hline $\begin{array}{c}\text { Talaromyces trachyspermus OU5 } \\
\text { (source NI) }\end{array}$ & $\begin{array}{l}\text { glucose, } \\
\text { urea }\end{array}$ & $\begin{array}{c}\text { FA }>92.5 \% \\
\text { PS: } 84.6 \%, P: 15.2 \%\end{array}$ & {$[60]$} \\
\hline $\begin{array}{l}\text { Fungal strain } \\
\text { (soil) }\end{array}$ & $\begin{array}{l}\text { glucose, } \\
\mathrm{NH}_{4} \mathrm{Cl}_{2}\end{array}$ & FA: 80 & [61] \\
\hline Phanerochaete chrysosporium (source NI) & glucose potatoes & $\begin{array}{l}\text { FA: } 93.5 \text { (coal slurry) } \\
\text { Acidic polysaccharide }\end{array}$ & [62] \\
\hline $\begin{array}{l}\text { Aspergillus flavus } \\
\text { (source NI) }\end{array}$ & $\begin{array}{l}\text { sucrose, } \\
\text { peptone }\end{array}$ & FA: $97.4 \%$ & [63] \\
\hline $\begin{array}{c}\text { Aspergillus niger } \\
\text { (source NI) }\end{array}$ & $\begin{array}{l}\text { palm oil mill effluent, glutamic } \\
\text { acid }\end{array}$ & FA: $81 \%$ PS: $66.8 \%$, P: $31.4 \%$ & [64] \\
\hline $\begin{array}{l}\text { Filamentous fungal strain } \\
\text { (river water) }\end{array}$ & potato dextrose agar & FA: $59.34-99.18 \%$ & [65] \\
\hline $\begin{array}{l}\text { Penicillum strain HHE-P7 } \\
\text { (source NI) }\end{array}$ & $\begin{array}{c}\text { glucose, } \\
\text { yeast extract }\end{array}$ & FA: $93 \%$ & [59] \\
\hline $\begin{array}{c}\text { Rhizopus sp. M9 } \\
\text { Rhizopus sp. M17 (soil) }\end{array}$ & potato starch wastewater, urea & FA: $90.2 \%$ & [66] \\
\hline $\begin{array}{l}\text { Scenedesmus quadricauda } \\
\text { (source NI) }\end{array}$ & nitrate & $\begin{array}{c}\text { FA: } 86.7 \% \\
\text { PS: } 56.7 \%, \text { P: } 41 \%\end{array}$ & [67] \\
\hline Scenedesmus obliquus AS-6-1 (source NI) & nitrate & $\begin{array}{c}\text { FA: } 80-85 \% \text { (for microalga) } \\
\text { PS: } 100 \% \\
\end{array}$ & [68] \\
\hline $\begin{array}{l}\text { Talaromyces sp. } \\
\quad \text { (soil) }\end{array}$ & $\begin{array}{l}\text { glucose, } \\
\text { urea }\end{array}$ & $\begin{array}{c}\text { FA: } 92.5 \% \\
\text { PS: } 84.6 \%, \text { P: } 15.2 \%\end{array}$ & [60] \\
\hline
\end{tabular}

Another strain of Aspergillus niger was reported to produce bioflocculant (composed of $66.8 \%$ polysaccharide and $31.4 \%$ protein) while growing in palm oil mill effluent supplemented with glutamic acid [64]. The produced bioflocculant was thermostable and able to flocculate industrial wastewater, especially with salinity up to $10 \%$ and in cold regions [63]. A fungal strain, Phanerochaete chrysosporium, produce an acidic polysaccharide having a higher FA of coal slurry (93.5\%) [62]. More recently and for the first time, the production of a proteoglycan (84.6\% polysaccharide and $15.2 \%$ proteins.) bioflocculant by Talaromyces sp. was reported. Interestingly, $20 \mathrm{mg} / \mathrm{L}$ of the proteoglycan allowed more than $92.5 \%$ FA [60].

Regarding the flocculating capability of microalgae, various species have been reported to produce flocculants during the stationary phase in batch cultures. However, fewer studies on microalgal flocculant properties have been recorded. For the first time, Guo et al. (2013) studied an extracellular biopolymer from Scenedesmus obliquus AS-6-1. The produced bioflocculant is a $127.9 \mathrm{kDa}$ polysaccharide that flocculates 
freely-suspended microalgal cells. However, another strain, Scenedesmus quadricauda, was shown to produce significant amounts of bioflocculant composed of sugar (56.7\%) and protein (41\%) [68]. The self-flocculation efficiency reached $96.8 \%$ at $\mathrm{pH} 7$ with biomass concentration $0.21-39 \mathrm{~g} / \mathrm{L}$ [67].

\section{Microorganism Growth Conditions for Bioflocculant Production}

Microbial growth bioflocculant production has been reported to be influenced by various factors such as carbon sources, nitrogen sources, oligoelements, and operating parameters (temperature, $\mathrm{pH}$, inoculum size, aeration rate, etc.). In order to increase the bioflocculant production, growth factors were optimized using statistical analyses. As reported before, a wide variety of microorganisms isolated from various sources, utilizing various nutrient sources and growing under various conditions, are able to produce bioflocculants with different characteristics.

At the beginning of the microbial bioflocculant investigation, media containing simple carbon and nitrogen were utilized for culturing new isolates. Carbon sources included sugar alcohols and organic acid. However, nitrogen sources included peptone, urea, yeast extract, $\mathrm{NH}_{4} \mathrm{Cl}$, etc. Tables $1-3$ show the favorable nutrient sources allowing the obtention of flocculanting polymers with significant FA. Glucose and yeast extract were efficient for several microbial strains such as Bacillus velezensis 40B [20] and Rhodococcus opacus [40], allowing the production of bioflocculants having different rates of FA ( $98 \%$ for Bacillus velezensis 40B and $22.5 \%$ for Rhodococcus opacus). L-glutamic acid has been reported to have an effective role in the culture of Bacillus mojavensis 32A and flocculant productivity [14]. Interestingly, using glucose for Penicillium sp. HHE-P7 allowed the production of bioflocculant having a FA of 95\% [59]. For Solibacillus silvestris W01, an optimal flocculant amount was reached with maltose [24]. Similarly, Zhang et al. (2010) [29] concluded that glucose and peptone were favorable for Proteus mirabilis to synthesize bioflocculant [29]. Compared with various nitrogen sources, peptone was highly appropriate for Paenibacillus elgii B69 to produce bioflocculant [25]. In the case of Aspergillus flavus, sucrose allowed the obtention of the maximum flocculant amount. However, this amount was negatively affected by fructose and glycerol. Interestingly, growth media supplemented by yeast extract and urea significantly enhanced the bioflocculant production [3]. Similarly, nitrogen sources such as $\mathrm{NaNO}_{3}, \mathrm{NH}_{4} \mathrm{Cl}$, and urea stimulate the growth of Klebsiella sp. ZZ-3, allowing the production of glycoprotein with FA ranging from $90.4 \%$ to $94.5 \%$ [31]. In addition, glycerol and ammonium enhance significantly the growth of Bacillus. However, the produced flocculant showed a lower FA of $23 \%$ [23].

Byproducts and wastes generated by the agroindustrial sector contain a considerable amount of nutrients (carbon, nitrogen, oligoelements, etc.) useful for microbial growth. In this context, multiple studies demonstrated that agroindustrial residues (sugarcane, starch molasses, corn-steep liquor, soybean juice, etc.), which are mainly composed of polysaccharides, could be used as substrates for microbial growth and bioflocculant production. Similarly, wastewater and sludge, which are abundant raw materials containing enough carbon, nitrogen, phosphorus, and micronutrients, could sustain microbial growth for bioflocculant production. According to Zhao et al. (2017), Rhizobium radiobacter and Bacillus sphaericus were able to synthesize flocculating materials while growing in wastewater supernatant of anaerobic co-digestion (corn straw and molasses wastewater) [22]. Methanol wastewater was used as a growth medium to produce bioflocculant useful for arsenite removal [34]. Potato starch wastewater was used for the culture of two strains of Rhizopus, allowing the production of an efficient bioflocculant MBF917 for wastewater treatment [66]. Moreover, Guo et al. (2014) reported the use of wastewater sludge to prepare biopolymers with flocculating activity exceeding 92\% [39].

The $\mathrm{pH}$ is also an important factor in the microbial culture. It was reported to affect the growth, bioflocculant production, and FA. Each microbial strain has an optimum $\mathrm{pH}$ for growth and bioflocculant production. The impact of $\mathrm{pH}$ can be illustrated by some examples reported for various microbial strains. For example, the $A$. flavus bioflocculant was produced at $\mathrm{pH}$ values ranging between 5 and 9 and the highest FA was obtained at neutral $\mathrm{pH}$ [3]. In the case of $S$. silvestris, the $\mathrm{pH}$ of growth was in the range $\mathrm{pH} 7-9$ with an optimum FA at $\mathrm{pH} 8$ [24]. For the C. daeguense strain, 
the maximum amount of flocculating material was reached at $\mathrm{pH} 6$ [29]. For Penicillium purpurogenum, pH 5.5 allowed the highest bioflocculant production [59].

Based on this reported information, it is vital to point out the role of $\mathrm{pH}$ during the flocculation procedure. In the presence of protein as a bioflocculant, an alkaline $\mathrm{pH}$ is required to ensure the flocculation [68]. However, polysaccharidic bioflocculants tolerate a $\mathrm{pH}$ ranging from slightly acidic to slightly alkaline conditions.

Similar to $\mathrm{pH}$, the temperature plays an essential role in microbial culture. Depending on the microbial stain, the growth temperature significantly affects the growth, the bioflocculant production, and FA. As reported by many authors, a high temperature may change the protein or peptide structure of the bioflocculant, causing polymer damage and reducing the FA. In addition, the inoculum size and the time course of bioflocculant production are considered two critical factors. Both the bioflocculant production characteristics and the FA varied during the growth depending on the microbial strain and the inoculum size. For many strains such as S. silvestris [24] and Streptomyces sp. [56], the bioflocculant was produced during the logarithmic growth phase. For others strains such as A.flavus, the bioflocculant was produced at the same time as the cell growth with a maximum at the stationary phase [3].

Therefore, it is apparent that every microorganism has its specific operating parameters to maximize bioflocculant yield and FA. In order to determine the precise time at which the microbial culture should be stopped, the growth medium composition (carbon, nitrogen, and growth factors) and culture operating parameters ( $\mathrm{pH}$, temperature, aeration, inoculum size, etc.) should be optimized for each microbial strain.

\section{Applications of Microbial Bioflocculants for Wastewater Treatment}

Microbial bioflocculants are eco-friendly materials, harmless and biodegradable. They are composed of polysaccharides, proteins, and glycoproteins. Their degraded intermediates are safe for humans and the environment. Moreover, microbial enzymes responsible for bioflocculant degradation are present in the environment (wastewater, sludge, soil, sea, etc.). Because of the increasing requirement for environmental quality, bioflocculant performance has been investigated for wastewater treatment to remove solids, organic pollutants, and heavy metals. Sludge conditioning was also studied using microbial bioflocculants.

\subsection{Microbial Flocculants for Turbidity and Organic Pollutant Removal}

The use of microbial flocculants as flocculating substances in various municipal and industrial wastewater was proven to cause a significant reduction in levels of SS, turbidity, and COD, as indicated in Table $4[25,27,57,60,69-73]$.

Table 4. Effluent treated by microbial flocculants for turbidity and organic pollutant removal.

\begin{tabular}{|c|c|c|c|}
\hline Effluents & Strains/Operating Conditions & Removal Efficiencies (\%) & Reference \\
\hline $\begin{array}{c}\text { Swine wastewater } \\
\text { COD }^{1}: 1372-3025 \mathrm{mg} / \mathrm{L} \\
\text { pH: } 7.5 \\
\text { Turbidity: } 230-800 \mathrm{NTU}\end{array}$ & $\begin{array}{c}\text { Bacillus xn12 } \\
\text { and Streptomyces } \times 17 \\
\text { Flocculant: } 9 \% v / v+\mathrm{CaCl}_{2}(1 \mathrm{wt} \%) \text { at } \mathrm{pH} 11\end{array}$ & $\begin{array}{c}\text { COD: } \\
42 \% \text { (xn12) } \\
46 \% \text { (xn17) } \\
\text { Turbidity: } \\
82 \% \text { (xn12) } \\
87 \% \text { (xn17) }\end{array}$ & [57] \\
\hline $\begin{array}{l}\text { Swine wastewater } \\
\text { COD: } 6746 \mathrm{mg} / \mathrm{L} \\
\mathrm{NH}_{4}^{+}-\mathrm{N}: 785 \mathrm{mg} / \mathrm{L} \\
\mathrm{TKN}^{2}: 1158 \mathrm{mg} / \mathrm{L} \\
\mathrm{TP}^{3}: 153 \mathrm{mg} / \mathrm{L} \\
\text { Turbidity: } 35,742 \mathrm{NTU}\end{array}$ & $\begin{array}{l}\text { Talaromyces trachyspermus OU5 } \\
\text { Flocculant: } 5 \% \text { v/v, } 15 \mathrm{~min}\end{array}$ & $\begin{array}{c}\text { COD: } 52.1 \% \\
\text { TKN: } 39.7 \% \\
\mathrm{NH}_{4}^{+}-\mathrm{N}: 18.6 \% \\
\text { TP: } 21.5 \% \\
\text { Turbidity: } 75 \%\end{array}$ & {$[60]$} \\
\hline
\end{tabular}


Table 4. Cont.

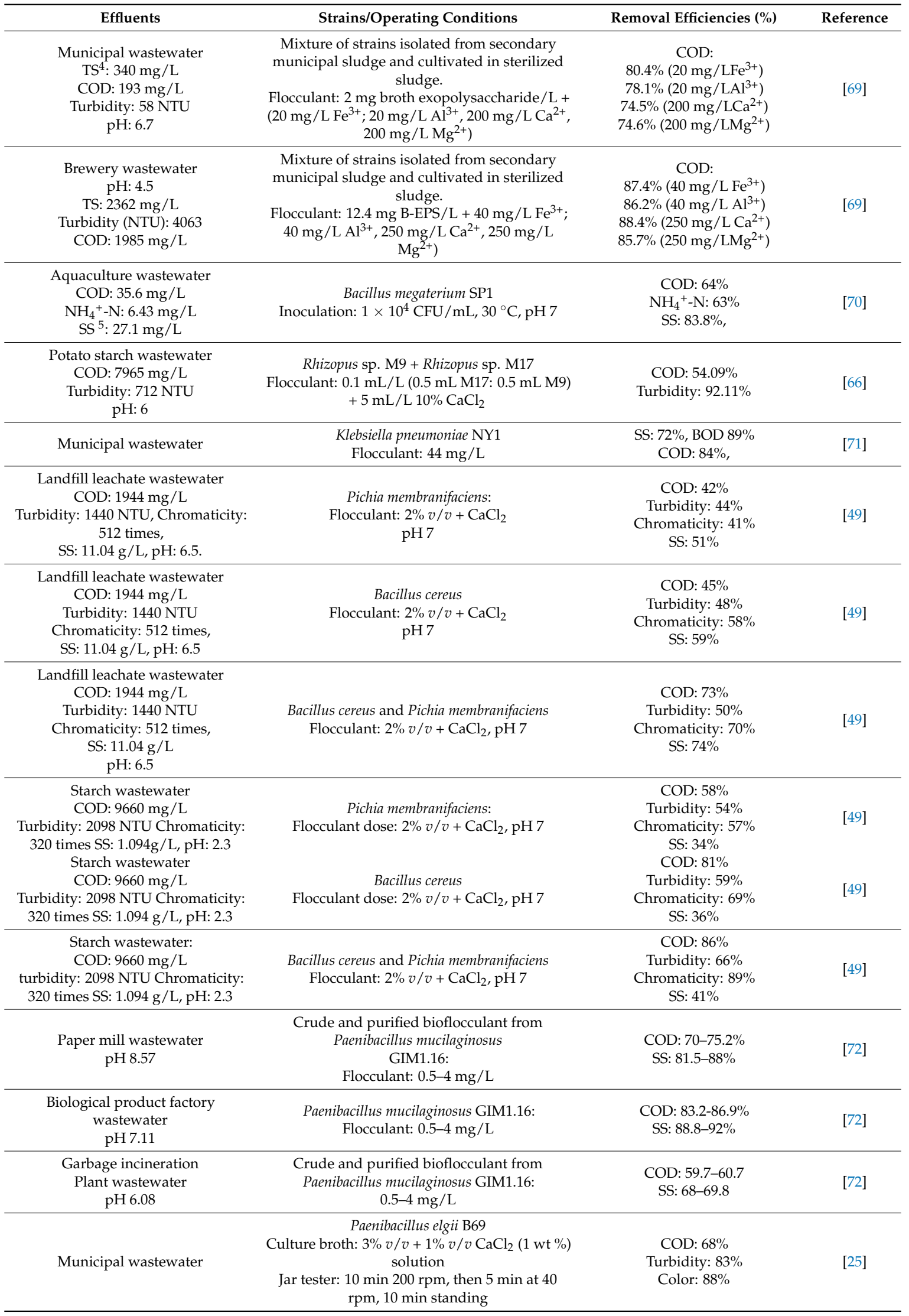


Table 4. Cont.

\begin{tabular}{|c|c|c|c|}
\hline Effluents & Strains/Operating Conditions & Removal Efficiencies (\%) & Reference \\
\hline $\begin{array}{l}\text { Tannery wastewater } \\
\text { COD: } 1082.2 \mathrm{mg} / \mathrm{L} \\
\text { Chrominance: } 2410.8 \mathrm{mg} / \mathrm{L} \\
\text { Nt: } 452.83 \mathrm{mg} / \mathrm{L}\end{array}$ & $\begin{array}{l}\text { Bacillus cereus CZ1001, B. subtilis } \\
\text { CZ1002, and B. fusiformis CZ1003 } \\
\text { Flocculant: } 0.2 \mathrm{~g} / \mathrm{L} \text { for COD, } 0.11 \mathrm{~g} / \mathrm{L} \text { for } \\
\text { Chrominance, } 0.11 \mathrm{~g} / \mathrm{L} \text { for } \mathrm{Nt}\end{array}$ & $\begin{array}{l}\text { COD: } 22.71-97 \% \\
\text { Chrominance: } 2.74-70.97 \% \\
\text { Nt: } 22.71-38.43 \%\end{array}$ & [73] \\
\hline $\begin{array}{c}\text { Ash-flushing wastewater } \\
\text { SS: } 18.33 \mathrm{~g} / \mathrm{L} \\
\text { pH: } 9.88\end{array}$ & $\begin{array}{c}\text { Pseudomonas veronii } \mathrm{L} 918 \\
\text { Flocculant: } 2.83 \mathrm{mg} / \mathrm{L}, \\
\text { Jar tester: rapid mixing for } 2 \mathrm{~min} \text {, followed by } \\
\text { slow mixing for } 1 \mathrm{~min}\end{array}$ & FA: $92.51 \%$ & [27] \\
\hline
\end{tabular}

Wastewater from various origins such as swine, municipal use, breweries, aquaculture, potato starch, landfill leachate, and tannery wastewater was subject to microbial flocculation. Studies were related to the optimization of culture conditions $(\mathrm{pH}$, temperature, inoculum size, bioflocculant dosage, etc.) in order to maximize bioflocculant yields, FA, and pollutant removal. Obtained results varied depending on the used strain for bioflocculant production and on the wastewater characteristics $\left(\mathrm{pH}, \mathrm{COD}, \mathrm{SS}, \mathrm{P}_{\mathrm{t}}, \mathrm{N}_{\mathrm{t}}\right.$, etc.). For example, Tang et al. (2014) reported a flocculant from Paenibacillus mucilaginosus with removal efficiencies of $70-75.2 \%$ and $81.5-88 \%$, respectively, for COD and SS from paper mill wastewater. The same bioflocculant allowed the removal of $88.8-92 \%$ of SS from biological factory wastewater, with $83.2-86.9 \%$ reduction of COD [73]. Similar work was conducted with garbage incineration plant wastewater ( $\mathrm{pH}$ 6.08), giving a COD ranging from $59.7 \%$ to $60.7 \%$ and $\mathrm{SS}$ removal in the range of $68-69.8 \%$. However, it is important to point out that the used polymer doses were between 0.5 and $4 \mathrm{mg} / \mathrm{L}$ [72].

Starch wastewater, characterized by high COD (COD: $9660 \mathrm{mg} / \mathrm{L})$, suspended solids (1.094 g/L), turbidity (2098 NTU), and low pH (2.3), was also subject to flocculation treatment by Bacillus cereus bioflocculant ( $2 \% v / v$ in the presence of $\mathrm{CaCl}_{2}$ at $\mathrm{pH} 7$ ). This treatment allowed $81 \%, 59 \%$, and $36 \%$ $\mathrm{COD}$, turbidity, and SS removal, respectively. These values were increased while using the mixture of bioflocculant of Bacillus cereus and Pichia membranifaciens bioflocculants in the same conditions, with maximum COD, turbidity, and SS reduction of $86 \%, 66 \%$, and $41 \%$, respectively. However, lower removal rates (COD, turbidity, and SS reduction of $58 \%, 54 \%$, and $34 \%$, respectively) were obtained using only Pichia membranifaciens bioflocculant [49]. The same combined flocculant mixture of Bacillus cereus and Pichia membranifaciens allowed the highest levels of COD (73\%), turbidity (50\%), and SS (74\%) removal for landfill leachate wastewater [49].

An interesting opportunity based on the direct addition of microbial strains to wastewater was performed by other authors. In this context, it was demonstrated that adding Bacillus megaterium SP1 (inoculation: $1 \times 10^{4} \mathrm{CFU} / \mathrm{mL}, 30^{\circ} \mathrm{C}, \mathrm{pH}$ ) to aquaculture wastewater could efficiently reduce the COD and SS levels and accelerate the bioflocculation process [70]. Therefore, a microbial polymer could substitute chemicals (e.g., $\mathrm{Fe}_{2}\left(\mathrm{SO}_{4}\right)_{3}, \mathrm{AlCl}_{3}$, etc.), during the treatment of industrial wastewater. A heterogeneous biopolymer prepared by a consortium (Rhizopus sp. M9 and M17) allowed many advantages (working at lower dose, without $\mathrm{pH}$ control, cheap cost of preparation, and significant elimination rates of turbidity and COD) while treating potato starch wastewater [66].

\subsection{Microbial Flocculants for Heavy Metal Removal}

In addition to organic pollutant removal, microbial bioflocculants were shown to be able to remove metals from an ion solution and real wastewater, as represented in Table 5 [17,22,34,44,74-79]. 
Table 5. Heavy metal removal by microbial flocculants.

\begin{tabular}{|c|c|c|c|}
\hline Effluents & Strains/Operating Conditions & Removal Efficiencies (\%) & Reference \\
\hline $\begin{array}{l}\text { Electroplating wastewater } \\
\text { Cr (VI): } 280 \mathrm{mg} / \mathrm{L}\end{array}$ & $\begin{array}{l}\text { Bacterial strains xn11 + xn7 } \\
\text { culture broth: } 2 \% v / v \\
\text { pH } 7.5,100 \mathrm{rpm}, 1 \mathrm{~min}\end{array}$ & $\mathrm{Cr}$ (VI): $28 \%$ & [74] \\
\hline $\begin{array}{c}\text { Chemical industry effluent } \\
\mathrm{As}^{3+}: 284 \mathrm{mg} / \mathrm{L} ; \mathrm{Cu}^{2+}: 2 \mathrm{mg} / \mathrm{L} ; \\
\mathrm{Pb}^{2+}: 1.6 \mathrm{mg} / \mathrm{L} ; \mathrm{Mn}^{2+}: 10.2 \mathrm{mg} / \mathrm{L} ; \\
\mathrm{Ni}^{2+}: 0.1 \mathrm{mg} / \mathrm{L} ; \mathrm{Al}^{3+}: 0.2 \mathrm{mg} / \mathrm{L} ; \\
\mathrm{Zn}^{2+}: 252 \mathrm{mg} / \mathrm{L} ; \mathrm{Cr}^{2+}: 0.93 \mathrm{mg} / \mathrm{L} ; \\
\mathrm{Cd}^{2+}: 0.1 \mathrm{mg} / \mathrm{L} ; \mathrm{Fe}^{2+}: 0.94 \mathrm{mg} / \mathrm{L} ; \\
\mathrm{Hg}^{2+}: 0.6 \mathrm{mg} / \mathrm{L}\end{array}$ & $\begin{array}{l}\text { Herbaspirillium sp. } \\
\text { flocculant: } 1000 \mathrm{mg} / \mathrm{L} \text {, } \\
\text { agitation: } 30 \mathrm{~s} .\end{array}$ & $\begin{array}{c}\mathrm{As}^{3+}: 26.6 \% ; \mathrm{Cu}^{2+}: 0 \% ; \mathrm{Pb}^{2+}: \\
72.9 \% ; \mathrm{Mn}^{2+}: 31.4 \% ; \mathrm{Ni}^{2+}: 0 \% \\
\mathrm{Al}^{3+}: 0 \% ; \mathrm{Zn}^{2+}: 39.5 \% ; \mathrm{Cr}^{2+}: \\
0.03 \% ; \mathrm{Cd}^{2+}: 0 \% ; \mathrm{Fe}^{2+}: 1.3 \% \\
\mathrm{Hg}^{2+}: 33.3 \%\end{array}$ & [75] \\
\hline $\begin{array}{c}\text { Biavin } 109 \text { medium blue dye } \\
\mathrm{As}^{3+}: 0 \mathrm{mg} / \mathrm{L} ; \mathrm{Cu}^{2+}: 0.2 \mathrm{mg} / \mathrm{L} ; \\
\mathrm{Pb}^{2+}: 0.02 \mathrm{mg} / \mathrm{L} ; \mathrm{Mn}^{2+}: 39.2 \mathrm{mg} / \mathrm{L} ; \\
\mathrm{Ni}^{2+}: 0.09 \mathrm{mg} / \mathrm{L} ; \mathrm{Al}^{3+}: 0.3 \mathrm{mg} / \mathrm{L} ; \mathrm{Zn}^{2+}: \\
1.21 \mathrm{mg} / \mathrm{L} ; \mathrm{Cr}^{2+}: 0.15 \mathrm{mg} / \mathrm{L} ; \mathrm{Cd}^{2+}: 0.96 \\
\mathrm{mg} / \mathrm{L} ; \mathrm{Fe}^{2+}: 3.01 \mathrm{mg} / \mathrm{L} ; \mathrm{Hg}^{2+}: 0 \mathrm{mg} / \mathrm{L}\end{array}$ & $\begin{array}{l}\text { Herbaspirillium sp. } \\
\text { Flocculant: } 1000 \mathrm{mg} / \mathrm{L} \\
\text { agitation: } 30 \mathrm{~s} .\end{array}$ & $\begin{array}{c}\mathrm{As}^{3+}: 0 \% ; \mathrm{Cu}^{2+}: 27.9 \% ; \mathrm{Pb}^{2+}: \\
25 \% ; \mathrm{Mn}^{2+}: 71.1 \% ; \mathrm{Ni}^{2+}: 89.2 \% \\
\mathrm{Al}^{3+}: 22.1 \% ; \mathrm{Zn}^{2+}: 8 \% ; \mathrm{Cr}^{2+}: \\
94.9 \% ; \mathrm{Cd}^{2+}: 0 \% ; \mathrm{Fe}^{2+}: 65.3 \% \\
\mathrm{Hg}^{2+}: 0 \%\end{array}$ & [75] \\
\hline $\begin{array}{c}\text { Whale dye } \\
\mathrm{As}^{3+}: 0 \mathrm{mg} / \mathrm{L} ; \mathrm{Cu}^{2+}: 0.18 \mathrm{mg} / \mathrm{L} ; \mathrm{Pb}^{2+}: \\
0.38 \mathrm{mg} / \mathrm{L} ; \mathrm{Mn}^{2+}: 35 \mathrm{mg} / \mathrm{L} ; \mathrm{Ni}^{2+}: 5.81 \\
\mathrm{mg} / \mathrm{L} ; \mathrm{Al}^{3+}: 0.39 \mathrm{mg} / \mathrm{L} ; \mathrm{Zn}^{2+}: 1.25 \\
\mathrm{mg} / \mathrm{L} ; \mathrm{Cr}^{2+}: 0.03 \mathrm{mg} / \mathrm{L} ; \mathrm{Cd}^{2+}: 0.96 \\
\mathrm{mg} / \mathrm{L} ; \mathrm{Fe}^{2+}: 1.3 \mathrm{mg} / \mathrm{L} ; \mathrm{Hg}^{2+}: 0 \mathrm{mg} / \mathrm{L}\end{array}$ & $\begin{array}{l}\text { Herbaspirillium sp. } \\
\text { Flocculant: } 1000 \mathrm{mg} / \mathrm{L} \\
\text { agitation: } 30 \mathrm{~s} .\end{array}$ & $\begin{array}{c}\mathrm{As}^{3+}: 0 \% ; \mathrm{Cu}^{2+}: 13.1 \% ; \mathrm{Pb}^{2+}: \\
5.5 \% ; \mathrm{Mn}^{2+}: 16 \% ; \mathrm{Ni}^{2+}: 17.4 \% \\
\mathrm{Al}^{3+}: 11.5 \% ; \mathrm{Zn}^{2+}: 16.8 \% ; \mathrm{Cr}^{2+}: \\
54.9 \% ; \mathrm{Cd}^{2+}: 0 \% ; \mathrm{Fe}^{2+}: 11.2 \% \\
\mathrm{Hg}^{2+}: 0 \%\end{array}$ & [75] \\
\hline Simulated electroplating wastewater & $\begin{array}{c}\text { Rhizobium radiobacter and Bacillus sphaericus } \\
\text { Flocculant: } 374 \mathrm{mg} / \mathrm{L} \\
\mathrm{pH} \text { 6, contact time: } 40 \mathrm{~min}\end{array}$ & $\begin{array}{l}\mathrm{Zn}^{2+}: 90 \% \\
\mathrm{Cu}^{2+}: 90 \% \\
\mathrm{Cr}^{6+}: 30 \% \\
\mathrm{Ni}^{2+}: 65 \%\end{array}$ & [22] \\
\hline $\begin{array}{l}\text { Metal ion solution } \\
\mathrm{Cr}_{2} \mathrm{O}_{7}^{2-}: 1 \mathrm{mg} / \mathrm{L} \\
\mathrm{Ni}^{2+}: 20 \mathrm{mg} / \mathrm{L}\end{array}$ & $\begin{array}{l}\text { Ruditapes philippinarum ZHT4-13 } \\
\text { Flocculant: } 2 \mathrm{~g} / \mathrm{L}, 1 \mathrm{~min}\end{array}$ & $\begin{array}{c}\mathrm{Ni}^{2+}: 19.2 \% \\
\mathrm{Cr}_{2} \mathrm{O}_{7}^{2-}: 69.3 \%\end{array}$ & [44] \\
\hline $\begin{array}{l}\text { Arsenite solution } \\
\mathrm{NaAsO}_{2}: 1.0 \mathrm{ppm}\end{array}$ & $\begin{array}{c}\text { Turicibacter sanguinis ZCY8 } \\
\text { Culture broth: } 1 \mathrm{~g} / \mathrm{L}, 20^{\circ} \mathrm{C} \text {. } \\
\text { Jar tester: } 2 \mathrm{~min} \text { at } 200 \mathrm{rpm} \text { followed by } 40 \\
\text { rpm for } 30 \mathrm{~min} \text {, settlement period: } 1-6 \mathrm{~min}\end{array}$ & Arsenite: $86.1 \%$ & [34] \\
\hline $\begin{array}{c}\text { Primary treated wastewater } \\
\text { Ni: } 48 \mathrm{mg} / \mathrm{L} ; \mathrm{Al}: 26.9 \mathrm{mg} / \mathrm{L} \\
\text { Fe: } 14.2 \mathrm{mg} / \mathrm{L} ; \mathrm{Zn}: 17.4 \mathrm{mg} / \mathrm{L} \\
\text { Cu: } 76 \mathrm{mg} / \mathrm{L}\end{array}$ & $\begin{array}{l}\text { Cloacibacterium normanense NK6 } \\
\text { Broth-EPS: } 35 \text { or } 50 \mathrm{mg} / \mathrm{L}, 250 \mathrm{rpm} \text { and } 30 \\
{ }^{\circ} \mathrm{C}, 0-12 \mathrm{~h} .\end{array}$ & $\begin{array}{l}\text { Ni: } 85 \% \text {; } \mathrm{Al}: 73 \% \\
\text { Fe: } 71 \% ; \mathrm{Zn}: 65 \% \\
\quad \mathrm{Cu}: 36 \%\end{array}$ & [76] \\
\hline $\begin{array}{l}\text { Synthetic wastewater } \\
\mathrm{Fe}^{3+}: 171-999 \mathrm{mg} / \mathrm{L} \\
\mathrm{Pb}^{2+}: 88-917 \mathrm{mg} / \mathrm{L}\end{array}$ & $\begin{array}{l}\text { Bacillus mucilaginosus. } \\
\text { Flocculant: } 40 \% \text { v/v, } \\
29^{\circ} \mathrm{C}, 150 \mathrm{r} / \mathrm{min}, 15 \mathrm{~min} .\end{array}$ & $\begin{array}{l}\mathrm{Fe}^{3+}: 15-27 \% \\
\mathrm{~Pb}^{2+}: 30-78 \%\end{array}$ & [77] \\
\hline $\begin{array}{l}\text { Synthetic wastewater } \\
\text { Arsenate: } 0.5 \mathrm{mg} / \mathrm{L} \\
\text { Arsenite: } 0.5 \mathrm{mg} / \mathrm{L}\end{array}$ & $\begin{array}{l}\text { Paenibacillus polymyxa ZCY-79 } \\
\text { Flocculant: } 120 \mathrm{mg} / \mathrm{L} \\
\text { pH 7, } 60 \mathrm{~min} .\end{array}$ & $\begin{array}{l}\text { Arsenate: } 98.9 \% \\
\text { Arsenite: } 84.6 \%\end{array}$ & [78] \\
\hline $\begin{array}{l}\text { Chromium solution } \\
\text { Cr (VI): } 10-100 \mathrm{mg} / \mathrm{L} \\
\text { pH: } 4-8\end{array}$ & $\begin{array}{l}\text { Bacillus licheniformis } \\
\text { Flocculant: } 2 \mathrm{~g} / \mathrm{L}, 150 \mathrm{rpm}, 1-2 \mathrm{~h} .\end{array}$ & $\mathrm{Cr}$ (VI): $88 \%$ (at pH 7) & [17] \\
\hline $\begin{array}{l}\text { Chromium solution } \\
\text { Cr (VI): } 10-100 \mathrm{mg} / \mathrm{L} \\
\text { pH: } 4-8\end{array}$ & $\begin{array}{l}\text { Bacillus firmus } \\
\text { Flocculant: } 2 \mathrm{~g} / \mathrm{L} \text {, } \\
150 \mathrm{rpm}, 1-2 \mathrm{~h} \text {. }\end{array}$ & Cr (VI): 77\% (at pH 7) & [17] \\
\hline $\begin{array}{l}\text { Aqueous solution } \\
\mathrm{Pb}\left(\mathrm{NO}_{3}\right)_{2}: 1 \mathrm{~g} / \mathrm{L}\end{array}$ & $\begin{array}{l}\text { Paenibacillu polymyxa CCTCC M206017 } \\
\text { Flocculant: } 4 \times 10^{-3} \%(w / w) \\
\text { Jar tester: } 1 \mathrm{~min} \text { at } 1500 \mathrm{rpm} \text { followed by } 40 \\
\text { rpm for } 2 \text { min, settlement period: } 1-6 \mathrm{~min} \\
\text { pH: } 8-9 .\end{array}$ & $\mathrm{Pb}: 99.85 \%$ & [79] \\
\hline
\end{tabular}

Among the works using real wastewater, a bacterial culture broth of two strains $(x n 11+x n 7)$ was used to flocculate electroplating wastewater (Cr (VI) initial concentration of $280 \mathrm{mg} / \mathrm{L})$. A $2 \%(v / v)$ inoculum acting for $1 \mathrm{~min}$ at $\mathrm{pH} 7.5$ and under agitation (100 rpm) achieved $28 \% \mathrm{Cr}$ (VI) elimination. This points to the adsorption properties of the bacterial bioflocculant for $\mathrm{Cr}$ (VI) [74].

More recently, it was demonstrated that Rhizobium radiobacter and Bacillus sphaericus were effective for the elimination of $\mathrm{Zn}^{2+}, \mathrm{Cu}^{2+}, \mathrm{Cr}^{6+}$, and $\mathrm{Ni}^{2+}$ from simulated electroplating wastewater. A bioflocculant dose of $374 \mathrm{mg} / \mathrm{L}$ (acting at $\mathrm{pH} 6$ for $40 \mathrm{~min}$ ) allowed $90 \%$ removal for both $\mathrm{Zn}^{2+}$ and $\mathrm{Cu}^{2+}, 65 \%$ for $\mathrm{Ni}^{2+}$, and only $30 \%$ for $\mathrm{Cr}^{6+}$ [22]. In addition, Yao et al. (2013) [77] reported significant removal of 
$\mathrm{Fe}^{3+}$ and $\mathrm{Pb}^{2+}$ from wastewater using B. mucilaginosus bioflocculant. Interestingly, heavy metals were removed by adsorption and by the formation of carbonate minerals in the presence of $\mathrm{CO}_{2}$, which can cause waste disposal problems [77]. Another microbial bioflocculant showed maximum removal efficiency of arsenic (84.6\%) and arsenite (98.9\%) from synthetic wastewater [78]. Also, a maximum $\mathrm{Pb}$ (II) ion removal efficiency of $99.85 \%$ was reported by Feng et al. (2013) [79]. This removal level could be related to the charge neutralization and adsorption bridging.

\subsection{Microbial Flocculants for Dye Decolorization}

Various microbial bioflocculants showed their decolorization ability for different textile dyes, as summarized in Table $6[17,44,49,73,74,80-83]$. However, the majority of studies were performed using a solution of mixed dyes (basic fuchsin, reactive black, terasil yellow, orange $G$, methylene blue, crystal violet, malachite green, etc.).

Table 6. Dye decolonization by microbial flocculants.

\begin{tabular}{|c|c|c|c|}
\hline Effluents & Strains/Operating Conditions & Removal Efficiencies & Reference \\
\hline $\begin{array}{l}\text { Dye solution } \\
\text { Basic fuchsin: } 100 \mathrm{mg} / \mathrm{L} \\
\text { Reactive black: } 50 \mathrm{mg} / \mathrm{L}\end{array}$ & $\begin{array}{l}\text { Bacterial strains: } x n 11+x n 7 \\
\text { Culture broth: } 3.3 \% v / v+\mathrm{CaCl}_{2}(1 \mathrm{wt} \%)\end{array}$ & $\begin{array}{c}\text { Basic fuchsin: } 93 \% \text { Reactive } \\
\text { Black: } 35 \%\end{array}$ & [74] \\
\hline $\begin{array}{l}\text { Dye solution } \\
\text { Terasil yellow: } 0.2 \mathrm{~g} / \mathrm{L}\end{array}$ & $\begin{array}{c}\text { Chryseomonas Luteola } \\
\text { Culture broth: } 0.13 \% v / v+\mathrm{CaCl}_{2}(1 \mathrm{wt} \%), \\
\mathrm{pH} 7\end{array}$ & $\begin{array}{l}\text { COD }^{1}: 33.25 \% \\
\text { Turbidity } 38.22 \%\end{array}$ & [80] \\
\hline $\begin{array}{l}\text { Dye solution } \\
\text { Methylene blue: } 50 \mathrm{mg} / \mathrm{L}\end{array}$ & $\begin{array}{c}\text { Ruditapes philippinarum } \\
\text { Flocculant: } 50 \mathrm{mg} / \mathrm{L} \text {, sodium dodecyl } \\
\text { sulphate SDS: } 8 \mathrm{mM}, \mathrm{Ca}^{2+}: 5 \mathrm{mM} \\
\text { Jar tester: } 5 \mathrm{~min} \text { at } 200 \mathrm{rpm} \text {, followed by } 30 \\
\text { min at } 40 \mathrm{rpm}, 1 \mathrm{~h} \text { settlement period }\end{array}$ & Methylene blue: $98.63 \%$ & [81] \\
\hline $\begin{array}{l}\text { Mixed dye from textile industrial } \\
\text { effluents (Dianix yellow S-6G, Dianix } \\
\text { navy CC, etc.) }\end{array}$ & $\begin{array}{l}\text { flocculant produced by mixture of various } \\
\text { strains }\end{array}$ & $\begin{array}{c}\text { Whale: }>97.04 \% \\
\text { Mediblue: } 80.61 \% \\
\text { Fawn: } 94.93 \% \\
\text { Mixed dye: } 81.64 \%\end{array}$ & [82] \\
\hline $\begin{array}{l}\text { Dye wastewater } \\
\text { Cibacron yellow: } 20-150 \mathrm{mg} / \mathrm{L} \\
\text { COD: } 40-190 \mathrm{mg} / \mathrm{L}\end{array}$ & $\begin{array}{c}\text { Sphingomonas paucimobilis } \\
\text { Culture broth: } 0.13 \% v / v+\mathrm{CaCl}_{2}(1 \mathrm{wt} \%) \\
\mathrm{pH} 7\end{array}$ & $\mathrm{COD}>80 \%$ & [83] \\
\hline $\begin{array}{c}\text { Printing and dyeing wastewater } \\
\text { COD: } 760 \mathrm{mg} / \mathrm{L} \\
\text { Turbidity: } 165 \text { NTU Chromaticity: } \\
1200 \text { times } \\
\text { SS }^{2}: 0.348 \mathrm{~g} / \mathrm{L}, \mathrm{pH}: 8.7\end{array}$ & $\begin{array}{c}\text { Pichia membranifaciens: } \\
\text { Culture broth: } 2 \% v / v+\mathrm{CaCl}_{2}(1 \mathrm{wt} \%), \mathrm{pH} \\
7\end{array}$ & $\begin{array}{c}\text { COD: } 45 \% \\
\text { Turbidity: } 49 \% \\
\text { Chromaticity: } 46 \% \\
\text { SS: } 58 \%\end{array}$ & [49] \\
\hline $\begin{array}{c}\text { Printing and dyeing wastewater } \\
\text { COD: } 760 \mathrm{mg} / \mathrm{L} \\
\text { Turbidity: } 165 \text { NTU Chromaticity: } \\
1200 \text { times } \\
\text { SS: } 0.348 \text { g/L, pH: } 8.7\end{array}$ & $\begin{array}{c}\text { Bacillus cereus and Pichia membranifaciens } \\
\text { Culture broth: } 2 \% v / v+\mathrm{CaCl}_{2}(1 \mathrm{wt} \%), \mathrm{pH} \\
7\end{array}$ & $\begin{array}{c}\text { COD: } 57 \% \\
\text { Turbidity: } 78 \% \\
\text { Chromaticity: } 78 \% \\
\text { SS: } 63 \%\end{array}$ & [49] \\
\hline $\begin{array}{c}\text { Tannery wastewater } \\
\text { COD: } 1082.2 \mathrm{mg} / \mathrm{L} \\
\text { Chrominance: } 2410.8 \mathrm{mg} / \mathrm{L} \\
\mathrm{Nt}^{3}: 452.83 \mathrm{mg} / \mathrm{L}\end{array}$ & $\begin{array}{l}\text { Bacillus cereus CZ1001, B. subtilis } \\
\text { CZ1002, and B. fusiformis CZ1003 } \\
\text { Flocculant: } 0.2 \mathrm{~g} / \mathrm{L} \text { for COD, } 0.11 \mathrm{~g} / \mathrm{L} \text { for } \\
\text { Chrominance, } 0.11 \mathrm{~g} / \mathrm{L} \text { for total nitrogen }\end{array}$ & $\begin{array}{l}\text { COD: } 22.71-25.97 \% \\
\text { Chrominance: } 12.74-70.97 \% \\
\text { Nt: } 22.71-38.43 \%\end{array}$ & [73] \\
\hline
\end{tabular}


Among these works, the removal of methylene blue, crystal violet and malachite green (at $10 \mathrm{mg} / \mathrm{L}$ ) was conducted using a flocculant from Ruditapes philippinarum ZHT4-13. A polymer dose of $2 \mathrm{~g} / \mathrm{L}$ applied for $1 \mathrm{~min}$ allowed removal percentages of $86.11 \%$ (for methylene blue), $97.84 \%$ (for malachite green), and 9.49\% (for crystal violet) [44]. The use of Ruditapes philippinarum flocculant for methylene blue (at $50 \mathrm{mg} / \mathrm{L}$ ) removal was optimized using a jar test Interestingly, higher removal $(98.63 \%)$ was obtained under optimal operating conditions of $50 \mathrm{mg} / \mathrm{L}$ of bioflocculant in the presence of sodium dodecyl sulphate $(8 \mathrm{mM})$ and $\mathrm{Ca}^{2+}(5 \mathrm{mM})$. The jar test operating conditions were rapid agitation (200 rpm for $5 \mathrm{~min}$ ), followed by slow agitation (40 rpm for $30 \mathrm{~min}$ ) and settlement (for $1 \mathrm{~h}$ ) [81]. Similarly, Bacillus firmus bioflocculant was also tested for a dye solution containing orange $\mathrm{G}$, methylene blue, crystal violet, and malachite green (at $10 \mathrm{mg} / \mathrm{L}$ ). In this experiment, optimal conditions (bioflocculant dose $=2 \mathrm{~g} / \mathrm{L}, 30 \mathrm{~min}$ agitation) allowed the removal of $90 \%$ for malachite green, $58 \%$ for orange $\mathrm{G}, 72 \%$ for methylene blue, and $84 \%$ for crystal violet [17].

Experiments with real wastewater were also conducted using a microbial culture broth or extracted bioflocculant. Among these experiments, a culture broth of microbial consortium (Bacillus cereus and Pichia membranifaciens) was used to treat printing and dyeing wastewater. A culture broth of $2 \% v / v, \mathrm{pH} 7$ and in the presence of $1 \%(v / v)$ of $\mathrm{CaCl}_{2}$ allowed the removal of $57 \%$ of COD, $63 \%$ of SS, and $78 \%$ of the turbidity [49]. In the same operating conditions, the use of each strain alone showed different performance. Bacillus cereus allowed the removal of $49 \%$ of COD, $73 \%$ of SS, and 70\% of the turbidity; however, Pichia membranifaciens removed $45 \%$ of COD, $58 \%$ of SS, and $49 \%$ of the turbidity [49]. The variability in performance could be explained by the variability of functional groups (hydroxyl, amino, phosphate, and carboxyl groups) present in the polymer molecules produced by each strain. Interestingly, the combination of the two strains may allow most substances present in wastewater to bond and, consequently, enhanced the removal efficiency.

In another study, tannery wastewater (initial COD: $1082.2 \mathrm{mg} / \mathrm{L}$ ) treatment was assessed using the bioflocculant that resulted from the growth of three bacterial strains (Bacillus cereus CZ1001, B. subtilis CZ1002, and B. fusiformis CZ1003). The study showed the variability of the optimum bioflocculant doses for the removal of COD, chrominance, and total nitrogen. It showed that $0.2 \mathrm{~g} / \mathrm{L}$ of the flocculant allowed COD removal percentages in the range $22.71-25.97 \%$, while a $0.11 \mathrm{~g} / \mathrm{L}$ dose allowed nitrogen removal percentages in the range $22.71-38.43 \%$. At the same concentration, the chrominance removal reached $12.74-70.97 \%$ [81]. Thus, microbial bioflocculant can be considered as a potential agent to treat industrial wastewater containing dyes in high concentrations. However, various parameters $(\mathrm{pH}$, temperature, flocculant doses, etc.) should be optimized depending on the characteristics of the wastewater to be treated.

\subsection{Microbial Flocculants for Sludge Dewatering}

In order to prepare sludge for dewatering processes, a conditioning process using chemical polymers should be applied. Sludge dewatering allowed the obtention of a product that was dry enough, thereby reducing the storage volume and limiting the energy used during the process of sludge incineration. As indicated above, the use of chemical polymers presents various disadvantages. Interestingly, using biomaterials for wastewater sludge conditioning represents a new sustainable technology. To the best of our knowledge, very few works have described the possibility of using microbial bioflocculants for sludge conditioning. Sludge dewatering was evaluated regarding dry solids (DS) and specific resistance to filtration (SRF). As indicated in Table 7 [29,84-88], bioflocculants showed significant results similar to those obtained with chemical polymers such as polyacrylamide (PAM), polyaluminum chloride (PAC), $\mathrm{FeCl}_{3}$, and $\mathrm{Al}_{2}\left(\mathrm{SO}_{4}\right)_{3}$. For example, Acidithiobacillus ferrooxidans flocculant improved the dewaterability of anaerobically digested sludge compared to PAM. The microbial polymer significantly reduced capillary suction time (CST) and the SRF of sludge by $74 \%$ and $89 \%$, respectively, and these values are higher than with PAM. Interestingly, the Acidithiobacillus ferrooxidans biopolymer reduces the moisture content of sludge to $70 \%$ and improves the clarity of the filtrate in terms of removal of total suspended solids and total dissolved solids [84]. Moreover, microbial bioflocculants offered the lowest optimum dosage, 
as reported by Guo and Ma (2015) [85]. An optimal dosage of $1.6 \mathrm{~g} / \mathrm{L}$ showed better performance (DS and $\mathrm{SRF}$ values) than $\mathrm{FeCl}_{3}$ and $\mathrm{Al}_{2}\left(\mathrm{SO}_{4}\right)_{3}$, which are added at an optimal dose of $8 \mathrm{~g} / \mathrm{L}$ [85].

Table 7. The use of microbial flocculants for sludge dewatering and comparison with synthetic polymer.

\begin{tabular}{|c|c|c|c|}
\hline Sludge & Treatment Conditions with Flocculant & $\begin{array}{c}\text { Sludge Characteristics after } \\
\text { Treatment }\end{array}$ & Reference \\
\hline $\begin{array}{l}\text { Anaerobically digested sludge } \\
\text { (municipal wastewater plant) }\end{array}$ & Acidithiobacillus ferrooxidans bioflocculant & $\mathrm{SRF}=0.36 \times 10^{13} \mathrm{~m} / \mathrm{kg}$ & \\
\hline $\mathrm{SRF}^{1}=3.29 \times 10^{13} \mathrm{~m} / \mathrm{kg}$ & (inoculation with $10^{8}$ cells $/ \mathrm{mL}, 30 \mathrm{~min}, 180 \mathrm{rpm}$ ) & $\mathrm{CST}=10.1 \mathrm{~s}$ & [84] \\
\hline \multirow[t]{3}{*}{$\mathrm{CST}^{2}=38.7 \mathrm{~s}$} & & Moisture: $70.3 \%$ & \\
\hline & & Organic matter: $74.5 \%$ & \\
\hline & & Calorific value: $4013 \mathrm{cal} / \mathrm{g}$ & \\
\hline $\begin{array}{l}\text { Anaerobically digested sludge } \\
\text { (municipal wastewater plant) }\end{array}$ & \multirow{5}{*}{ Polyacrylamide (PAM) 67\% and 89\% } & $\mathrm{SRF}=1.08 \times 10^{13} \mathrm{~m} / \mathrm{kg}$ & \multirow{5}{*}[84]{} \\
\hline $\mathrm{SRF}^{1}=3.29 \times 10^{13} \mathrm{~m} / \mathrm{kg}$ & & $\mathrm{CST}=16.25 \mathrm{~s}$ & \\
\hline \multirow{3}{*}{$\mathrm{CST}^{2}=38.7 \mathrm{~s}$} & & Moisture: $71.2 \%$ & \\
\hline & & Organic matter: $66 \%$ & \\
\hline & & Calorific value: $3815 \mathrm{cal} / \mathrm{g}$ & \\
\hline Secondary sludge (municipal) & \multirow{3}{*}{ Bioflocculant from pre-treated sludge $(1.5 \mathrm{~g} / \mathrm{L})$} & $\mathrm{DS}=22.5 \%$ & \multirow{11}{*}[85]{} \\
\hline $\mathrm{DS}^{3}=13.2 \%$ & & $\mathrm{SRF}=3.4 \times 10^{12} \mathrm{~m} / \mathrm{kg}$ & \\
\hline $\mathrm{SRF}=11.3 \times 10^{12} \mathrm{~m} / \mathrm{kg}$ & & & \\
\hline & \multirow{2}{*}{$\mathrm{Al}_{2}\left(\mathrm{SO}_{4}\right)_{3}(8 \mathrm{~g} / \mathrm{L}, \mathrm{pH} 6.5)$} & $\mathrm{DS}=15.9 \%$ & \\
\hline & & $\mathrm{SRF}=4.7 \times 10^{12} \mathrm{~m} / \mathrm{kg}$ & \\
\hline & \multirow{2}{*}{ PAM (0.15 g/L, pH 7.5) } & $\mathrm{DS}=24.2 \%$ & \\
\hline & & $\mathrm{SRF}=3.2 \times 10^{12} \mathrm{~m} / \mathrm{kg}$ & \\
\hline & \multirow{2}{*}{ PAC (4 g/L, pH 7.5) } & DS $=20.6 \%$ & \\
\hline & & $\mathrm{SRF}=3.8 \times 10^{12} \mathrm{~m} / \mathrm{kg}$ & \\
\hline & \multirow{2}{*}{$\mathrm{FeCl}_{3}(8 \mathrm{~g} / \mathrm{L} \cdot \mathrm{pH} 6.5)$} & $\mathrm{DS}=16.4 \%$ & \\
\hline & & $\mathrm{SRF}=4.5 \times 10^{12} \mathrm{~m} / \mathrm{kg}$ & \\
\hline Secondary sludge (municipal) & Bioflocculant of Paenibacillus polymyxa & DS = $21.7 \%$ & \multirow{3}{*}[86]{} \\
\hline $\mathrm{DS}=13.2 \%$ & $(1.5 \mathrm{~g} / \mathrm{L}, \mathrm{pH} 7.5)$ & $\mathrm{SRF}=3.6 \times 10^{12} \mathrm{~m} / \mathrm{kg}$ & \\
\hline \multicolumn{3}{|l|}{$\mathrm{SRF}=11.3 \times 10^{12} \mathrm{~m} / \mathrm{kg}$} & \\
\hline Secondary sludge & Bioflocculant of Paenibacillus polymyxa & $\mathrm{DS}=20.8 \%$ & \multirow{3}{*}[87]{} \\
\hline $\mathrm{DS}=13.2 \%$ & $(1.5 \mathrm{~g} / \mathrm{L}, \mathrm{pH} 7.5)$ & $\mathrm{SRF}=3.9 \times 10^{12} \mathrm{~m} / \mathrm{kg}$ & \\
\hline \multicolumn{3}{|l|}{$\mathrm{SRF}=11.3 \times 10^{12} \mathrm{~m} / \mathrm{kg}$} & \\
\hline Secondary sludge & $\begin{array}{l}\text { Bioflocculant of Klebsiella pneumoniae } \\
\qquad(0.1 \% / \mathrm{wt} / \mathrm{v})\end{array}$ & DS $=59.97 \%$ & \multirow{5}{*}[88]{} \\
\hline $\mathrm{SRF}=11.64 \times 10^{12} \mathrm{~m} / \mathrm{kg}$ & $\mathrm{Al}_{2}\left(\mathrm{SO}_{4}\right)_{3}$ & $\mathrm{SRF}=4.66 \times 10^{12} \mathrm{~m} / \mathrm{kg}$ & \\
\hline \multicolumn{3}{|c|}{ PAC } & \\
\hline & & $\mathrm{SRF}=6.25 \times 10^{12} \mathrm{~m} / \mathrm{kg}$ & \\
\hline & & $\mathrm{SRF}=5 \times 10^{12} \mathrm{~m} / \mathrm{kg}$ & \\
\hline Secondary sludge & Bioflocculant of P. mirabilis TJ-1 & $\mathrm{SFR}=9 \times 10^{5} \mathrm{~mL} / \mathrm{kg}$ & \multirow{5}{*}[29]{} \\
\hline $\mathrm{SRF}=29 \times 10^{5} \mathrm{~mL} / \mathrm{kg}$ & Poly (acrylamide P(AM-DMC): TJ-F1 + CaCl & & \\
\hline $\mathrm{pH} 6.23$ & & $\mathrm{SFR}=15 \times 10^{5} \mathrm{~mL} / \mathrm{kg}$ & \\
\hline Moisture: $96.81 \%$ & & $\mathrm{SFR}=2.5 \times 10^{5} \mathrm{~mL} / \mathrm{kg}$ & \\
\hline VSS $^{4} /$ TSS $^{5}: 55 \%$ & & & \\
\hline
\end{tabular}

\section{Conclusions}

This review has considered the potential employment of microbial flocculants as a substitute for conventional chemical agents in wastewater treatment. Efforts have focused on the isolation, identification, and characterization of effective bioflocculant-producing microorganisms. Interestingly, microorganisms isolated from several sources, utilizing various nutrient sources and growing under 
various conditions, are able to produce bioflocculants with different characteristics. Microbial growth conditions (strain, inoculum, nutrient sources, operating parameters, etc.) are studied in order to determine a typical procedure to maximize both bioflocculant production and flocculating activity. Bioflocculant chemical characteristics such as polymer content are related to the microbial strain and substrates used. Hence, data related to the conditions of microbial flocculant production are required to establish a strategy for scientific research and the commercial application of biopolymers in wastewater treatment. As discussed above, the potential use of microbial flocculants for wastewater treatment has been verified. They have shown significant results in removing pollutants from wastewater such as suspended solids, turbidity, COD, total nitrogen, dye, and heavy metals. At a laboratory scale, many examples of bioflocculants displayed significant flocculating activity, where the efficiency of pollutant removal exceeded $90 \%$ depending on the microbial strain used to produce the flocculant and on the wastewater characteristics. Therefore, extensive research is required to determine the optimal bioflocculation procedures for each type of wastewater. Also, in order to understand the bioflocculation mechanism, more experiments needed to be conducted taking into account the modifications in different treatment systems. Finally, the efficacy of the bioflocculation should be examined at a large scale, in real conditions and for a variety of wastewater systems, followed by a techno-economic assessment.

Author Contributions: Conceptualization, F.B.R.; S.M.S. and W.M.; investigation, F.B.R.; data curation, F.B.R. and S.M.S.; writing-original draft preparation, F.B.R. and S.M.S.; writing—review and editing, W.M.; supervision, W.M.; project administration, F.B.R.; S.M.S. and W.M.

Funding: Not applicable.

Acknowledgments: The authors would like to express their gratitude to King Khalid University, Saudi Arabia for providing administrative and technical support. The authors would also like to express their gratitude to the Research Center of Advanced Materials, King Khalid University, Saudi Arabia for support. Likewise the authors thanks University of Bisha, Kingdom of Saudi Arabia.

Conflicts of Interest: There are no conflicts of interest to declare.

\section{References}

1. Zheng, Y.; Ye, Z.L.; Fang, X.L.; Li, Y.H.; Cai, W.M. Production and characteristics of a bioflocculant produced by Bacillus sp. F19. Bioresour. Technol. 2008, 99, 7686-7691. [CrossRef] [PubMed]

2. Lee, C.S.; Robinson, J.; Chong, M.F. A review on application of flocculants in wastewater treatment. Process. Saf. Environ. Prot. 2014, 92, 489-508. [CrossRef]

3. Aljuboori, A.H.R.; Idris, A.; Abdullah, N.; Mohamad, R. Production and characterization of a bioflocculant produced by Aspergillus flavus. Bioresour. Technol. 2013, 127, 489-493. [CrossRef] [PubMed]

4. Buczek, S.B.; Cope, W.G.; McLaughlin, R.A.; Kwak, T.J. Acute toxicity of polyacrylamide flocculants to early life stages of freshwater mussels. Environ. Toxicol. Chem. 2017, 36, 2715-2721. [CrossRef] [PubMed]

5. Ben Rebah, F.; Siddeeg, S.M. Cactus an eco-friendly material for wastewater treatment: A review. JMES 2017, 8, 1770-1782.

6. Wang, L.; Hu, J.; Zhao, Y.; Lu, X.; Zhang, Q.; Niu, Q. Effects of Aluminium on $\beta$-Amyloid (1-42) and Secretases (APP-Cleaving Enzymes) in Rat Brain. Neurochem. Res. 2014, 39, 1338-1345. [CrossRef] [PubMed]

7. Kerr, J.L.; Lumsden, J.S.; Russell, S.K.; Jasinska, J.; Goss, G.G. Effects of anionic polyacrylamide products on gill histopathology in juvenile rainbow trout (Oncorhynchus mykiss). Environ. Toxicol. Chem. 2014, 33, 1555-1562. [CrossRef] [PubMed]

8. Wauer, G.; Teien, H.C. Risk of acute toxicity for fish during aluminum application to hardwater lakes. Sci. Total Environ. 2010, 408, 4020-4025. [CrossRef] [PubMed]

9. Zhuang, X.; Wang, Y.; Li, Q.; Yan, S.; He, N. The production of bioflocculants by Bacillus licheniformis using molasses and its application in the sugarcane industry. Biotechnol. Bioprocess Eng. 2012, 17, 1041-1047. [CrossRef]

10. Agunbiade, M.; Pohl, C.; Ashafa, O. Bioflocculant production from Streptomyces platensis and its potential for river and wastewater treatment. Braz. J. Microbiol. 2018, 49, 731-741. [CrossRef] [PubMed]

11. Gao, J.; Bao, H.Y.; Xin, M.X.; Liu, Y.X.; Li, Q.; Zhang, Y.F. Characterization of a bioflocculant from a newly isolated Vagococcus sp. W31. J. Zhejiang Univ. Sci. B 2006, 7, 186-192. [CrossRef] [PubMed] 
12. Al-Wasify, R.S.; Al-Sayed, A.A.; Saleh, S.M.; Aboelwafa, A.M. Bacterial exopolysaccharides as new natural coagulants for surface water treatment. Int. J. Pharm. Tech. Res. 2015, 8, 198-207.

13. Liu, W.; Cong, L.; Yuan, H.; Yang, J. The mechanism of kaolin clay flocculation by a cation-independent bioflocculant produced by Chryseobacterium daeguense W6. AIMS Environ. Sci. 2015, 2, 169-179. [CrossRef]

14. Elkady, M.F.; Farag, S.; Zaki, S.; Abu-Elreesh, G.; Abd-El-Haleem, D. Bacillus mojavensis strain 32A, a bioflocculant-producing bacterium isolated from an Egyptian salt production pond. Bioresour. Technol. 2011, 1020, 8143-8151. [CrossRef] [PubMed]

15. Giri, S.S.; Harshiny, M.; Sen, S.S.; Sukumaran, V.; Park, S.C. Production and characterization of a thermostable bioflocculant from Bacillus subtilis F9, isolated from wastewater sludge. Ecotoxicol. Environ. Saf. 2015, 121, 45-50. [CrossRef] [PubMed]

16. Li, Z.; Zhong, S.; Lei, H.Y.; Chen, R.W.; Yu, Q.; Li, H.L. Production of a novel bioflocculant by Bacillus licheniformis X14 and its application to low temperature drinking water treatment. Bioresour. Technol. 2009, 100, 3650-3656. [CrossRef] [PubMed]

17. Devi, K.K.; Natarajan, K.A. Production and characterization of bioflocculants for mineral processing applications. Int. J. Miner. Process. 2015, 137, 15-25. [CrossRef]

18. Makapela, B.; Okaiyeto, K.; Ntozonke, N.; Nwodo, U.U.; Green, E.; Mabinya, L.V.; Okoh, A.I. Assessment of Bacillus pumilus isolated from fresh water milieu for bioflocculant production. Appl. Sci. 2016, 6, 211. [CrossRef]

19. Zaki, S.; Farag, S.; Abu Elreesh, G.; Elkady, M.; Nosier, M.; Abd El Haleem, D. Characterization of bioflocculants produced by bacteria isolated from crude petroleum oil. Int. J. Environ. Sci. Technol. 2011, 8, 831-840. [CrossRef]

20. Zaki, S.A.; Elkady, M.F.; Farag, S.; Abd-El Haleem, D. Characterisation and flocculation properties of a carbohydrate bioflocculant from newly isolated Bacillus velezensis 40B. J. Environ. Biol. 2013, 34, 51-58. [PubMed]

21. Arafa, R.A.; El-Rouby, M.N.; Abass, H.A.; Abo El-khier, Z.A. Bioflocculants produced by bacterial isolates from egyptian soil 1-characterization and application of extracellular bioflocculants and nanoparticles for treatment of river nile water. IOSR J. Pharma. Biol. Sci. 2014, 9, 103-114. [CrossRef]

22. Zhao, G.; Ji, S.; Sun, T.; Ma, F.; Chen, Z. Production of bioflocculants prepared from wastewater supernantant of anaerobic co-digestion of corn straw and molasses wastewater treatment. BioResources 2017, 12, 1991-2003. [CrossRef]

23. Bhunia, B.; Mukhopadhy, D.; Goswami, S.; Mandal, T.; Dey, A. Improved production, characterization and flocculation properties of poly $(\gamma)$-glutamic acid produced from Bacillus subtilis. J. Biochem. Technol. 2012, 3, 389-394.

24. Wan, C.; Zhao, X.Q.; Guo, S.L.; Alam, M.A.; Bai, F.W. Bioflocculant production from Solibacillus silvestris W01 and its application in cost-effective harvest of marine microalga Nannochloropsis oceanica by flocculation. Bioresour. Technol. 2013, 135, 207-212. [CrossRef] [PubMed]

25. Li, O.; Lu, C.; Liu, A.; Zhu, L.; Wang, P.; Qian, C.; Jiang, X.; Wu, X. Optimization and characterization of polysaccharide-based bioflocculant produced by Paenibacillus elgii B69 and its application in wastewater treatment. Bioresour. Technol. 2013, 134, 87-93. [CrossRef] [PubMed]

26. Wei, W.; Zhang, J.; Dong, W.; Guo, H.; Diao, J.; Wang, C. Screening and characterization of the bacteria which can produce flocculants and degrade of phenol. IPCBEE 2014, 66, 111-114.

27. Liu, H.; Wang, H.; Qin, H. Characteristics of hydrogen and bioflocculant production by a transposon-mutagenized strain of Pantoea agglomerans BH18. Int. J. Hydrogen Energy. 2016, 41, 22786-22792. [CrossRef]

28. Liu, W.J.; Wang, K.; Li, B.Z.; Yuan, H.L.; Yang, J.S. Production and characterization of an intracellular bioflocculant by Chryseobacterium daeguense W6 cultured in low nutrition medium. Bioresour. Technol. 2010, 101, 1044-1048. [CrossRef] [PubMed]

29. Zhang, Z.; Xia, S.; Zhao, J.; Zhang, J. Characterization and flocculation mechanism of high efficiency microbial flocculant TJ-F1 from Proteus mirabilis. Colloids Surf. B Biointerfaces 2010, 75, 247-251. [CrossRef] [PubMed]

30. Mandal, A.K.; Yadav, K.K.; Sen, I.K.; Kumar, A.; Chakraborti, S.; Islam, S.S.; Chakraborty, R. Partial characterization and flocculating behavior of an exopolysaccharide produced in nutrient-poor medium by a facultative oligotroph Klebsiella sp. PB12. J. Biosci. Bioeng. 2013, 115, 76-81. [CrossRef] [PubMed] 
31. Yin, Y.J.; Tian, Z.M.; Tang, W.; Li, L.; Song, L.Y.; McElmurry, S.P. Production and characterization of high efficiency bioflocculant isolated from Klebsiella sp. ZZ-3. Bioresour. Technol. 2014, 171, 336-342. [CrossRef] [PubMed]

32. Liu, Z.Y.; Hu, Z.Q.; Wang, T.; Chen, Y.Y.; Zhang, J.; Yu, J.R.; Zhang, T.; Zhang, Y.F.; Li, Y.L. Production of novel microbial flocculants by Klebsiella sp. TG-1 using waste residue from the food industry and its use in defecating the trona suspension. Bioresour. Technol. 2013, 139, 265-271. [CrossRef] [PubMed]

33. Pathak, M.; Sarma, H.K.; Bhattacharyya, K.G.; Subudhi, S.; Bisht, V.; Lal, B.; Devi, A. characterization of a novel polymeric bioflocculant produced from bacterial utilization of $n$-hexadecane and its application in removal of heavy metals. Front. Microbiol. 2017, 8, 1-15. [CrossRef] [PubMed]

34. Cao, C.; Zhang, Y.; Chen, L.; Liu, J.; Mao, K.; Li, K.; Zhou, J. Production of a bioflocculant from methanol wastewater and its application in arsenite removal. Chemosphere 2015, 141, 274-281. [CrossRef] [PubMed]

35. Li, Y.; Li, Q.; Hao, D.; Hu, Z.; Song, D.; Yang, M. Characterization and flocculation mechanism of an alkali-activated polysaccharide flocculant from Arthrobacter sp. B4. Bioresour. Technol. 2014, 170, 574-577. [CrossRef] [PubMed]

36. Manivasagan, P.; Kang, K.H.; Kim, D.G.; Kim, S.K. Production of polysaccharide-based bioflocculant for the synthesis of silver nanoparticles by Streptomyces sp. Int. J. Biol. Macromol. 2015, 77, 159-167. [CrossRef] [PubMed]

37. Batta, N.; Subudhi, S.; Al Banwari, L.; Devi, A. Isolation of a lead tolerant novel bacterial species, Achromobacter sp TL-3 assessment of biofloculant activity. Indian J. Exp. Biol. 2013, 51, 1004-1011. [PubMed]

38. Czemierska, M.; Szczes, A.; Pawlik, A.; Wiater, A.; Wilkołazka, A.J. Production and characterisation of exopolymer from Rhodococcus Opacus. Biochem. Eng. J. 2016, 112, 143-152. [CrossRef]

39. Guo, J.; Yang, C.; Peng, L. Preparation and characteristics of bacterial polymer using pre-treated sludge from swine wastewater treatment plant. Bioresour. Technol. 2014, 152, 490-498. [CrossRef] [PubMed]

40. Czemierska, M.; Szczes, A.; Hołysz, L.; Wiater, A.; Jarosz-Wilkołazka, A. Characterisation of exopolymer R-202 isolated from Rhodococcus rhodochrous and its flocculating properties. Eur. Polym. J. 2017, 88, 21-33. [CrossRef]

41. Amjres, H.; Béjar, V.; Quesada, E.; Carranza, D.; Abrini, J.; Sinquin, C.; Ratiskol, J.; Colliec-Jouault, S.; Llamas, I. Characterization of haloglycan, an exopolysaccharide produced by Halomonas stenophila HK30. Int. J. Biol. Macromol. 2015, 72, 117-124. [CrossRef] [PubMed]

42. Sam, S.; Kucukasik, F.; Yenigun, O.; Nicolaus, B.; Oner, E.T.; Yukselen, M.A. Flocculating performances of exopolysaccharides produced by a halophilic bacterial strain cultivated on agro-industrial waste. Bioresour. Technol. 2011, 102, 1788-1794. [CrossRef] [PubMed]

43. Li, Q.; Liu, H.L.; Qi, Q.S.; Wang, F.S.; Zhang, Y.Z. Isolation and characterization of temperature and alkaline stable bioflocculant from Agrobacterium sp. M-503. New Biotechnol. 2010, 27, 789-794. [CrossRef] [PubMed]

44. Gao, Q.; Zhu, X.H.; Mu, J.; Zhang, Y.; Dong, X.W. Using Ruditapes philippinarum conglutination mud to produce bioflocculant and its applications in wastewater treatment. Bioresour. Technol. 2009, 100, 4996-5001. [CrossRef] [PubMed]

45. Liu, C.; Wang, K.; Jiang, J.H.; Liu, W.J.; Wang, J.Y. A novel bioflocculant produced by a salt-tolerant, alkaliphilic and biofilm-forming strain Bacillus agaradhaerens C9 and its application in harvesting Chlorella minutissima UTEX2341. Biochem. Eng. J. 2015, 93, 166-172. [CrossRef]

46. Cui, H.; Zhang, S. Study of separation and flocculation characteristics of a bioflocculant MBF B31. J. Chem. Pharm. Res. 2014, 6, 1187-1192.

47. Ambarsari, L.; Artika, I.M.; Susanti, H.E. Characterization of bioflocculant producing-bacteria isolated from tapioca waste water. HAYATI J. Biosci. 2011, 18, 193-196.

48. Ntsaluba, L.; Agundiade, O.; Mabinya, L.; Okoh, A. Studies on bioflocculant production by Methylobacterium sp. Obi isolated from a freshwater environment in South Africa. Afr. J. Microbiol. Res. 2015, 5, 4533-4540. [CrossRef]

49. Zhang, F.; Jiang, W.; Wang, X.; Ji, X.; Wang, Y.; Zhang, W.; Chen, J. Biodegradation and Bioremediation of Polluted Systems: Culture Condition Effect on Bioflocculant Production and Actual Wastewater Treatment Application by Different Types of Bioflocculants; IntechOpen Limited: London, UK, 2015; Chapter 2. [CrossRef]

50. Ugbenyen, A.; AI Okoh, A. Characteristics of a bioflocculant produced by a consortium of Cobetia and Bacillus species and its application in the treatment of wastewaters. Water SA 2014, 40, 139-144. [CrossRef] 
51. Ugbenyen, A.M.; Vine, N.; Simonis, J.J.; Basson, A.K.; Okoh, A.I. Characterization of a bioflocculant produced from the consortium of three marine bacteria of the genera Cobetia and Bacillus and its application for wastewater treatment. J. Water Sanit. Hyg. Dev. 2015, 5, 81-88. [CrossRef]

52. Zhang, Z.Q.; Bo, L.; Xia, S.Q.; Wang, X.J.; Yang, A.M. Production and application of a novel bioflocculant by multiple-microorganism consortia using brewery wastewater as carbon source. J. Environ. Sci. 2007, 19, 667-673. [CrossRef]

53. Mishra, V.K.; Sharma, G. Effect of Factors on Activity of Bioflocculant Produced by Bacterial Strain Isolated from Waste Water Sample. In Energy Technologies, Climate Change and Environmental Sustainability: Innovative Perspective; Krishisanskriti: New Delhi, India, 2014.

54. Okaiyeto, K.; Nwodo, U.U.; Mabinya, L.V.; Okoh, A.I. Characterization of a bioflocculant produced by a consortium of Halomonas sp. Okoh and Micrococcus sp. Leo. Int. J. Environ. Res. Public Health 2013, 10, 5097-5110. [CrossRef] [PubMed]

55. Cosa, S.; Okoh, A. Bioflocculant production by a consortium of two bacterial species and its potential application in industrial wastewater and river water treatment. Pol. J. Environ. Stud. 2014, 23, 689-696.

56. Nwodo, U.U.; Green, E.; Mabinya, L.V.; Okaiyeto, K.; Rumbold, K.; Lawrence, C.; Obi, L.C.; Okoh, A.I. Bioflocculant production by a consortium of Streptomyces and Cellulomonas species and media optimization via surface response model. Colloids Surf. B Biointerfaces 2014, 116, 257-264. [CrossRef] [PubMed]

57. Zhang, X.; Sun, J.; Liu, X.; Zhou, J. Production and flocculating performance of sludge bioflocculant from biological sludge. Bioresour. Technol. 2013, 146, 51-56. [CrossRef] [PubMed]

58. Sun, J.; Zhang, X.; Miao, X.; Zhou, J. Preparation and characteristics of bioflocculants from excess biological sludge. Bioresour. Technol. 2012, 126, 362-366. [CrossRef] [PubMed]

59. Liu, L.; Cheng, W. Characteristics and culture conditions of a bioflocculant produced by Penicillium sp. Biomed. Environ. Sci. 2010, 23, 213-218. [CrossRef]

60. Fang, D.; Shi, C. Characterization and flocculability of a novel proteoglycan produced by Talaromyces trachyspermus OU5. J. Biosci. Bioeng. 2016, 121, 52-56. [CrossRef] [PubMed]

61. Abraham, J.; Singh, N.; Janapal, Y.; Kumar, N.U. Optimized bioflocculant production from Fungi using response surface methodology. Int. J. Pharm. Tech. Res. 2015, 8, 230-235.

62. Dongchen, Z.; Zhixiang, H.; Zhiyong, L.; Tao, W. Experimental research on phanerochaete chrysosporium as coal microbial flocculant. Int. J. Min. Sci. Technol. 2013, 23, 521-524.

63. Aljuboori, A.H.R.; Idris, A.; Al-joubory, H.H.R.; Uemura, Y.; Ibn Abubakar, B.S.U. Flocculation behavior and mechanism of bioflocculant produced by Aspergillus flavus. J. Environ. Manag. 2015, 150, 466-471. [CrossRef] [PubMed]

64. Aljuboori, A.H.R.; Uemura, Y.; Osman, N.B.; Yusup, S. Production of a bioflocculant from Aspergillus niger using palm oil mill effluent as carbon source. Bioresour. Technol. 2014, 171, 66-70. [CrossRef] [PubMed]

65. Jebun, N.; Al-Mamun, A.; Alam, M.Z.; Abdul Karim, M.I.; Raus, R.A. Evaluation of entrapment potentiality and turbidity removal efficiency of Fungi. J. Technol. 2015, 77, 23-28. [CrossRef]

66. Pu, S.; Qin, L.; Che, J.; Zhang, B.; Xu, M. Preparation and application of a novel bioflocculant by two strains of Rhizopus sp. using potato starch wastewater as nutrilite. Bioresour. Technol. 2014, 162, 184-191. [CrossRef] [PubMed]

67. Aljuboori, A.H.R.; Uemura, Y.; Thanh, N.T. Flocculation and mechanism of self-flocculating lipid producer microalga Scenedesmus quadricauda for biomass harvesting. Biomass Bioenergy 2016, 93, 38-42. [CrossRef]

68. Guo, S.L.; Zhao, X.Q.; Wan, C.; Huang, Z.Y.; Yang, Y.L.; Alam, M.A.; Ho, S.H.; Bai, F.W.; Chang, J.S. Characterization of flocculating agent from the self-flocculating microalga Scenedesmus obliquus AS-6-1 for efficient biomass harvest. Bioresour. Technol. 2013, 145, 285-289. [CrossRef] [PubMed]

69. More, T.T.; Yan, S.; Tyagi, R.D.; Surampalli, R.Y. Biopolymer production kinetics of mixed culture using wastewater sludge as a raw material and the effect of different cations on biopolymer applications in water and wastewater treatment. Water Environ. Res. 2016, 88, 425-437. [CrossRef] [PubMed]

70. Luo, L.; Zhao, Z.; Huang, X.; Du, X.; Wang, C.; Li, J.; Wang, L.; Xu, Q. Isolation, identification, and optimization of culture conditions of a bioflocculant-producing bacterium Bacillus megaterium SP1 and its application in aquaculture wastewater treatment. BioMed Res. Int. 2016, 2016, 2758168. [CrossRef] [PubMed] 
71. Nie, M.; Yin, X.; Jia, J.; Wang, Y.; Liu, S.; Shen, Q.; Li, P.; Wang, Z. Production of a novel bioflocculant MNXY1 by Klebsiella pneumoniae strain NY1 and application in precipitation of cyanobacteria and municipal wastewater treatment. J. App. Microbiol. 2011, 111, 547-558. [CrossRef] [PubMed]

72. Tang, W.; Song, L.; Li, D.; Qiao, J.; Zhao, T.; Zhao, H. Production, characterization, and flocculation mechanism of cation independent, $\mathrm{pH}$ tolerant, and thermally stable bioflocculant from Enterobacter sp. ETH-2. PLoS ONE 2014, 9, e114591. [CrossRef] [PubMed]

73. Yang, Q.; Ming, H.; Zhao, X.; Zhao, C.; Guan, X. Screening of bioflocculant and preliminary application to treatment of tannery wastewater. J. Resid. Sci. Technol. 2015, 12, 177-181. [CrossRef]

74. Zhang, C.L.; Cui, Y.N.; Wang, Y. Bioflocculant produced from bacteria for decolorization, Cr removal and swine wastewater application Sustain. Environ. Res. 2012, 22, 129-134.

75. Lin, J.; Harichund, C. Industrial effluent treatments using heavy-metal removing bacterial bioflocculants. Water SA 2011, 37, 265-270. [CrossRef]

76. Nouha, K.; Kumar, R.S.; Tyagi, R.D. Heavy metals removal from wastewater using extracellular polymeric substances produced by Cloacibacterium normanense in wastewater sludge supplemented with crude glycerol and study of extracellular polymeric substances extraction by different methods. Bioresour. Technol. 2016, 212, 120-129. [CrossRef] [PubMed]

77. Yao, M.; Lian, B.; Dong, H.; Hao, J.; Liu, C. Iron and lead ion adsorption by microbial flocculants in synthetic wastewater and their related carbonate formation. J. Environ. Sci. 2013, 25, 2422-2428. [CrossRef]

78. Zhao, H.; Zhong, C.; Chen, H.; Yao, J.; Tan, L.; Zhang, Y.; Zhou, J. Production of bioflocculants prepared from formaldehyde wastewater for the potential removal of arsenic. J. Environ. Manag. 2016, 172, 71-76. [CrossRef] [PubMed]

79. Feng, J.; Yang, Z.; Zeng, G.; Huang, J.; Xu, H.; Zhang, Y.; Wei, S.; Wang, L. The adsorption behavior and mechanism investigation of $\mathrm{Pb}(\mathrm{II})$ removal by flocculation using microbial flocculant GA1. Bioresour. Technol. 2013, 148, 414-421. [CrossRef] [PubMed]

80. Syafalni, S.; Abustan, I.; Ismail, N.; Kwan, T.S. Production of bioflocculant by Chryseomonas luteola and its application in dye wastewater treatment. Mod. Appl. Sci. 2012, 6, 13-20.

81. Yang, Z.; Li, M.; Yu, M.; Huang, J.; Xu, H.; Zhou, Y.; Song, P.; Xu, R. A novel approach for methylene blue removal by calcium dodecyl sulphate enhanced precipitation and microbial flocculant GA1 flocculation. Chem. Eng. J. 2016, 303, 1-13. [CrossRef]

82. Buthelezi, S.P.; Olaniran, A.O.; Pillay, B. Textile dye removal from wastewater effluents using bioflocculants produced by indigenous bacterial isolates. Molecules 2012, 17, 14260-14274. [CrossRef] [PubMed]

83. Sanayei, Y.; Ismail, N.; Teng, T.T.; Morad, N. Studies on flocculating activity of bioflocculant from closed drainage. Int. J. Chem. 2010, 2, 168-173. [CrossRef]

84. Kurade, M.B.; Murugesan, K.; Selvam, A.; Yu, S.A.M.; Wong, J.W.C. Sludge conditioning using biogenic flocculant produced by Acidithiobacillus ferrooxidans for enhancement in dewaterability. Bioresour. Technol. 2016, 217, 179-185. [CrossRef] [PubMed]

85. Guo, J.; Ma, J. Bioflocculant from pre-treated sludge and its applications in sludge dewatering and swine wastewater pretreatment. Bioresour. Technol. 2015, 196, 736-740. [CrossRef] [PubMed]

86. Guo, J.; Nengzi, K.L.; Zhao, J.; Zhang, Y. Enhanced dewatering of sludge with the composite of bioflocculant MBFGA1 and P(AM-DMC) as a conditioner. Appl. Microbiol. Biotechnol. 2015, 99, 2989-2998. [CrossRef] [PubMed]

87. Guo, J.; Zhang, Y.; Zhao, J.; Zhang, Y.; Xiao, X.; Wang, B.; Shu, B. Characterization of a bioflocculant from potato starch wastewater and its application in sludge dewatering. Appl. Microbiol. Biotechnol. 2015, 99, 5429-5437. [CrossRef] [PubMed]

88. Liu, J.; Ma, J.; Liu, Y.; Yang, Y.; Yue, D.; Wang, H. Optimized production of a novel bioflocculant M-C11 by Klebsiella sp. and its application in sludge dewatering. J. Environ. Sci. 2014, 26, 2076-2083. [CrossRef] [PubMed]

(C) 2018 by the authors. Licensee MDPI, Basel, Switzerland. This article is an open access article distributed under the terms and conditions of the Creative Commons Attribution (CC BY) license (http:/ / creativecommons.org/licenses/by/4.0/). 